\title{
Rather complements than substitutes: Firm value effects of capital structure and financial hedging decisions
}

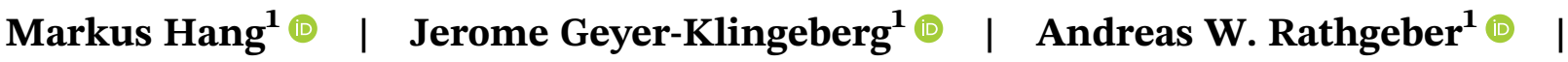 \\ Stefan Stöckl ${ }^{2}$
}

${ }^{1}$ Institute of Materials Resource

Management, Faculty of Mathematics and Natural Sciences, University of Augsburg, Augsburg, Germany

${ }^{2}$ Department of Finance, Audit, Accounting and Control, ICN Business School Nancy-Metz (Grande école) CEREFIGE, Metz, France

\section{Correspondence}

Andreas W. Rathgeber, Institute of Materials Resource Management, Faculty of Mathematics and Natural Sciences, University of Augsburg, Alter Postweg 101, Augsburg 86135, Germany. Email: andreas.rathgeber@mrm.uniaugsburg.de

\begin{abstract}
The aim of this study is to analyze the interaction between capital structure decisions and risk management decisions as well as the channels through which they add value to firms. Competing theories are considered in an integrated path model, which we test by means of meta-analytic structural equation modelling (MASEM). This meta-analysis is based on 6,312 reported results, which are manually collected from 411 empirical studies. We find that capital structure mediates the relation between corporate financial hedging and firm value. In this regard, active risk management positively affects leverage by providing greater debt capacities. Furthermore, leverage has a negative impact on firm value. Hence, capital structure and financial hedging decisions appear rather as complements instead of substitutes. This implies that managers should leave additional debt capacities unused and instead use additional internal funds arising from active risk management to carry out profitable projects and research and development activities. Overall, corporate hedging is found to especially add value to a firm by lowering bankruptcy risks and underinvestment risks.
\end{abstract}

\section{KEYWOR D S}

capital structure, firm value, meta-analysis, risk management, structural equation model

J E L C L A S S I F I C A T I O N

C83; G32

\section{1 | INTRODUCTION}

Both theory and empirical evidence are mixed regarding the questions of when and how capital structure and risk management decisions affect firm value. Consequently, the question arises whether financial decisions should be integrated in corporate decision-making following the maximization of economic gains - strictly speaking, the maximization of firm values - as a leading objective. Following the neoclassical Modigliani-Miller theorem supposing a firm's cost of capital to be independent from financial decisions (Modigliani \& Miller, 1958), managerial decision makers should neglect financial decisions and instead focus on maximizing operational performance. Nevertheless, companies frequently refer to financial decisions in their reports. For example, the 
German airline Lufthansa proclaims that "financial strategy is the basis for all main planning and decision-making processes" (Lufthansa Group, 2017). For the Dutch technology company Philips, "risk management forms an integral part of the business planning and review cycle" (Royal Philips, 2017). And the Austrian oil and gas company OMV states that "strategic commodity risks are managed centrally [...]" using "financial instruments only" (OMV, 2017).

In line with the observation that companies often account for financial decision as integral part of corporate management, more recent theory states that financial decisions might affect firm value. However, there is a diversity of hypotheses for different theoretical relations. Allayannis and Weston (2001) hypothesize in their seminal work that corporate hedging activities might have a direct impact on firm value. Among others, this might be reasoned by the fact that the use of financial hedging instruments (to mitigate secondary risks) may be a signal for good management quality, which is thus rewarded by shareholders (Lookman, 2004). Alternatively, capital structure might have a mediating role in the relation between corporate hedging and firm value. In this regard, firms may benefit from higher debt capacity if corporate hedging activities reduce the probability of financial distress in the first step of the mediating effect (Leland, 1998; Ross, 1977). This is also empirically confirmed by Graham and Rogers (2002). Since firms are expected to not fully exploit additional debt capacity, a second source of added value might stem from lower distress costs resulting from unused debt capacity (Leland, 1998). In contrast, Froot, Scharfstein, and Stein (1993) developed a concept that corporate hedging is negatively related to leverage in the first step of the mediating effect. Accordingly, firms benefit from corporate hedging since it helps to coordinate internal funds (Loss, 2012), which in turn avoids costly external financing. In the second step of the mediating effect, leverage might be negatively related to firm value, as argued by Fama and French (1998). They hypothesize negative information of debt concerning the firm's (expected) profitability. According to the alternative traditional tax hypothesis, leverage might have a positive impact on firm value (Fama \& French, 1998). Since interest rates are deductible, firm value increases by the market value of corporate tax savings. This brief excerpt from existing theory illustrates the previously mentioned diversity of hypotheses for different theoretical relations in this field of research.

Besides the diversity in theory, there exist many empirical studies in the field. However, they suffer from heterogeneous results as Aretz and Bartram (2010), Arnold, Rathgeber, and Stöckl (2014), and GeyerKlingeberg, Hang, and Rathgeber (2019b), as well as
Fauver and Naranjo (2010) observe in the primary research on the determinants of corporate hedging. This heterogeneity is also detected in the field of capital structure determinants (among others, An, Li, \& Yu, 2016; Hang, Geyer-Klingeberg, Rathgeber, \& Stöckl, 2018; Hovakimian, 2006; Strebulaev, 2007), as well as for the hedging and firm value link (among others, Allayannis \& Weston, 2001; Carter, Rogers, \& Simkins, 2006; GeyerKlingeberg, Hang, \& Rathgeber, 2019a; Gilje \& Taillard, 2017; Jin \& Jorion, 2006). Accordingly, the channels through which financial decisions affect firm value are ambiguous. In a recent publication, Gilje and Taillard (2017) address this issue and find that corporate hedging adds value to the firm by reducing bankruptcy risks and underinvestment problems. More advanced theories attempt to bring the separate but complementary research questions together by simultaneously modelling different financial management decisions (among others, Froot et al., 1993; C.-M. Lin, Phillips, \& Smith, 2008; Ross, 1977). However, a general comprehension of each field is difficult due the strongly mixed evidence, which indeed underscores the complexity of the interactions. Due to the importance and scope of financial management in research and practice, the rationales and implications of financial decisions are also a central issue of contemporary strategic management research (among others, Carney, Gedajlovic, Heugens, van Essen, \& van Oosterhout, 2011; Gamba \& Triantis, 2013; Hoskisson, Chirico, Zyung, \& Gambeta, 2017; Liu, van Jaarsveld, Batt, \& Frost, 2014).

The aim of this study is to analyze the interactions between capital structure decisions and corporate hedging decisions, as well as the channels through which they add value to the firm. As a theoretical basis, we derive a path model incorporating the alternative theories mentioned above. This allows statistically testing of the direct impact of corporate hedging activities on firm value as opposed to the mediating role of capital structure for this relation. Overall, this approach contributes to the literature as follows. (a) The analysis of mediating effects contributes to how financial decisions interact and influence firm value referring to the causality among these variables. (b) Testing several moderating factors allows the analysis of the heterogeneity among the reported results and might reveal when corresponding effects particularly occur. To analyze the path model, we apply statistical meta-analysis by combining 6,312 reported results, which are manually collected from 411 existing empirical primary studies from the past 30 years, and based on a cumulative 2,572,731 firm observations.

To address our first research question of how corporate capital structure and financial hedging decisions interact, we simultaneously test the competing theories 
on the nexus among capital structure, corporate hedging, and firm value via meta-analytic structural equation modelling (MASEM; Cheung \& Chan, 2005; Viswesvaran $\&$ Ones, 1995), as recommended by Aretz and Bartram (2010). ${ }^{1}$ To the best of our knowledge, our study presents the first application of MASEM in finance. This methodology has been recently developed to serve as an excellent tool for testing new hypotheses and identifying mediating effects at a meta-level (among others, Bergh et al., 2016; Bilgili, Calderon, Allen, \& Kedia, 2016; Carney et al., 2011; Carney, van Essen, Gedajlovic, \& Heugens, 2015; Duran, Kammerlander, van Essen, \& Zellweger, 2016; Marcus, Taylor, Hastings, Sturm, \& Weigelt, 2016; Rosenbusch, Rauch, \& Bausch, 2013; Zeegers, Colonnesi, Stams, \& Meins, 2017). Here, we especially make use of MASEM to analyze bivariate relations from the diverse research strands in an integrated way (Bergh et al., 2016), instead of separately aggregating the reported results for each bivariate relation in our path model. The MASEM approach contributes to the literature, as it considers the full body of existing empirical literature in the two fields - capital structure and hedging - and integrates them together with the determinants of both financial decisions. Based on the integrated evidence, we can test path models considering simultaneous effects among the variables, especially the mediating effects between capital structure and hedging. This allows new insights for the research on the combined and interacting effects among corporate financial decisions.

For a deeper understanding of the conditions for when capital structure and hedging decisions impact firm value as stated in our second research question, we contrast our MASEM results with the results derived from (univariate) Hedges and Olkin-type meta-analysis (HOMA; Hedges \& Olkin, 1985), which is, in general, a simple mean effect calculation of the reported results for each bivariate relation. In addition, HOMA allows exploring the heterogeneity in reported results by studying the influence of several moderating factors in the form of subgroup analyses, following, among others, Geyskens, Steenkamp, and Kumar (2006), Lee, Kirkpatrick-Husk, and Madhavan (2014), and Bilgili et al. (2016). Since the apparent heterogeneity is typically greater than expected from random sampling error, several factors could be responsible for the wide betweenstudy variability of reported results (Aretz \& Bartram, 2010; Harris \& Raviv, 1991; C.-M. Lin et al., 2008; Stanley \& Doucouliagos, 2012). To address this problem, we explicitly test for the influence of study characteristics and data characteristics. In recent meta-analysis from diverse research fields in management, economics, and finance, these factors are consistently judged to be reasonable as they are already confirmed to be related to the results reported in empirical studies (Bilgili et al., 2016; Carney et al., 2015; Doucouliagos \& Ulubaşoğlu, 2008; Geyer-Klingeberg, Hang, \& Rathgeber, 2020; Marano, Arregle, Hitt, Spadafora, \& van Essen, 2016; van Essen, Otten, \& Carberry, 2015). Thereby, we also address different aspects of county-level differences on the impact of capital structure and hedging decisions on corporate firm value. Especially, we analyze differences in the effects driven by regional differences, economic development, and the law system. The examination of the heterogeneity drivers of the empirical findings for capital structure and hedging provides new evidence on the conditions driving the extent of the interactions of those effects and their influence on firm value. Furthermore, meta-analysis allows assessing whether or not publication selection bias is present in a research field and correct for its distorting effects. In general, publication selection bias refers to the phenomenon that specific estimates are systematically underrepresented in empirical literature (Rosenthal, 1979). In other words, publication selection bias exists when researchers prefer to report statistically significant results (Stanley, 2005).

The remainder of this paper is structured as follows. In Section 2, we present the theory behind the structural relations in our path model. Subsequently, we introduce the applied data set and meta-analytic methodologies in Section 3. Section 4 continues with the presentation of our results. After discussing the outcomes and limitations, Section 5 concludes the paper.

\section{2 | THE ROLE OF CAPITAL STRUCTURE AND HEDGING DECISIONS ON FIRM VALUE}

The starting point of this paper's theoretical considerations is given by Modigliani and Miller (1958). In their article they state that a firm's market value is independent from financing decisions, assuming conditions of a perfect capital market. This conclusion holds for debtequity choices (in the narrower sense) as well as for corporate hedging decisions (in the broader sense) (Bessembinder, 1991; Smith \& Stulz, 1985). Consequently, managers following the maximization of firm values as a leading objective should ignore financial decisions and instead focus on maximizing operational performance. In contrast to this, more recent financial theory assumes that market frictions create possibilities for financing decisions to increase firm value via maximization of shareholder value (Jensen \& Meckling, 1976; Kraus \& Litzenberger, 1973; Myers, 1984). This also sparks debate on the role of corporate hedging for capital structure decisions and firm value. In the following, we present the 
theoretical hypotheses for the integrated path model, which is empirically tested in our meta-analysis, and presented in Figure 1.

\section{1 | The direct effect of corporate hedging on firm value}

We aim at shedding light on the effects of corporate hedging activities on firm value. In this regard, we especially investigate the direct effect of corporate hedging on firm value as well as the indirect effect via capital structure. Starting with the direct impact of corporate hedging on firm value, Allayannis and Weston (2001) hypothesize in their pioneering article that corporate hedging activities might also have a direct impact on firm value. In this regard, Lookman (2004) concludes that hedging secondary risks is a positive indicator of management quality (while hedging primary risk is supposed to mean the opposite). Furthermore, hedging activities create significant cash flow gains (e.g., due to positive developments of the spot price over the contracted forward price), which directly increase firm value without affecting firm risk (Adam \& Fernando, 2006). For these reasons, hedging firms might benefit from a higher market valuation by equity investors. In contrast, firm values should not be

\section{Path model}

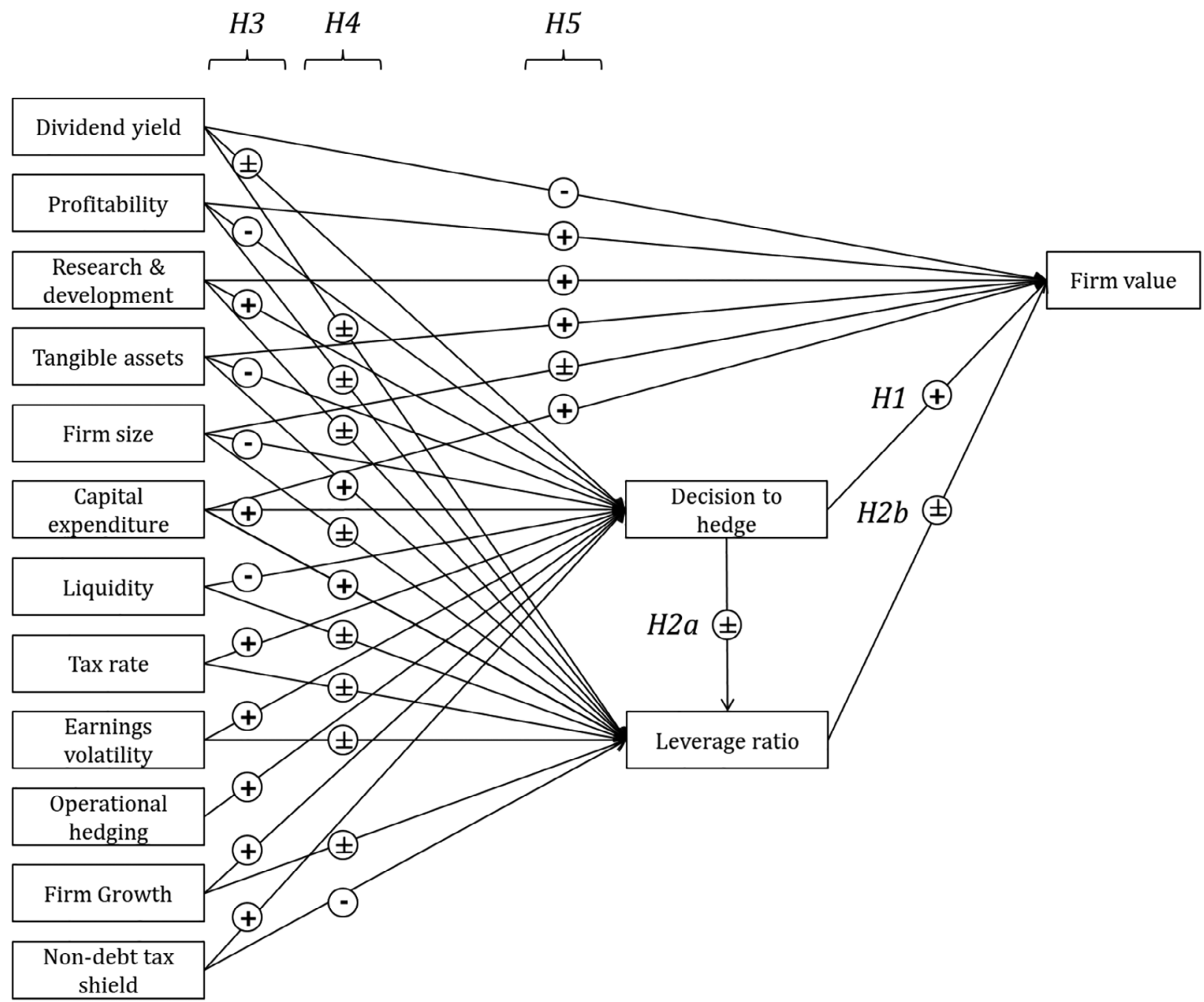

F I G U RE 1 Path model. This figure presents the hypothetical path model as derived from theoretical literature. It contains the determinants of corporate hedging, corporate financing strategy, and firm value. Additionally, we explicitly model the relations among these three endogenous variables. The assumed causalities among the variables derived from theoretical literature are displayed by arrows, and the direction of the influence is shown in circles. "+" and "-"correspond to a hypothetical positive or negative influence, respectively. " \pm " means that there are competing accepted theories for both directions 
affected by hedging activities according to the managerial utility maximization theory (Jin \& Jorion, 2006). In this regard, risk-averse managers are assumed to hedge firm risks, if their personal wealth depends on the firm value and hedging on the firm level is less costly than on a personal level (Smith \& Stulz, 1985). Hence, managers usually claim extra compensation for such non-diversifiable risks or hedge these risks at the firm level. However, if the costs of hedging are smaller than the reduction in extra compensation, firm value increases (Smith \& Stulz, 1985). Consequently, we formulate the following hypothesis:

H1 Corporate hedging activities have a positive impact on firms' market values.

\subsection{The mediating function of capital structure}

Continuing with the indirect impact of corporate hedging on firm value, several researchers state a positive influence of corporate hedging activities on leverage ratio in the first step of the mediating effect (Graham \& Rogers, 2002; Leland, 1998; C.-M. Lin et al., 2008; Stulz, 1996). By smoothing a firm's outcomes, hedging activities increase debt capacities with regard to the realization of tax benefits from higher interest deductions (Leland, 1998). In contrast, Jensen and Meckling (1976) develop the idea that corporate hedging is negatively related to leverage ratio. Accordingly, a smaller amount of hedging activities for a firm creates value in terms of high levels of external financing - dependent on a high probability of upper tail outcomes. According to Froot et al. (1993), hedging might also avoid costly external financing. It can be argued that when external capital is more costly than internal funds, hedging activities contribute to the availability of internal funds and, thus, alter a firm's leverage by lowering earnings volatility. Thereby a firm benefits from additionally profitable investment opportunities. These considerations produce the following hypothesis:

H2a Corporate hedging activities have a direct (positive or negative) impact on a firm's capital structure.

The subsequent second step of the indirect effect indicates a potential relation between capital structure and firm value. According to the traditional tax hypothesis, debt might have a positive impact on firm value (Fama \& French, 1998). Since interest rates are deductible, firm value increases by the market value of corporate tax savings. Furthermore, firms might also increase performance by investing additional external capital in profitable projects (Graham \& Rogers, 2002; C.-M. Lin et al., 2008). Since firms are expected to not fully exploit the additional debt capacity, a further source of added value comes from lower distress costs due to unused debt capacity (Leland, 1998). The latter is, however, not seen to be a dominant force in the relation between leverage and firm value (Ross, 1977). Alternatively, following the findings by Fama and French (1998), an increasing leverage ratio might also negatively affect firm value because of the negative signal effect of debt concerning the firm's (expected) profitability (Miller \& Rock, 1985). This conclusion could be drawn by the fact that debt causes agency problems between stockowners and bondholders (Jensen \& Meckling, 1976; Myers, 1977). Hence, profitable firms might prefer equity financing in order to avoid potential agency problems of debt. Moreover, the pecking order theory developed by Myers and Majluf (1984) underscores a preference for investing with internal funds in particular. If liquidity is great enough, a firm would carry out all projects with a positive net present value without causing information asymmetry problems by issuing debt or equity. Hence, a firm would prefer to reserve excess liquidity and to lower leverage in order to enhance firm value. The associated hypothesis can be formulated as follows:

H2b Capital structure has a direct (positive or negative) impact on firm value.

\section{3 | Further model paths}

As commonly employed in prior primary studies, we also account for the most frequently used control variables in our path model.

In the field of corporate hedging, the following theories build on the presence of market frictions in order to explain rationales for corporate hedging. Following Aretz and Bartram, these market frictions can be summarized as asymmetric information, agency conflicts of equity, agency conflicts of debt, costs of bankruptcy and financial distress, and corporate taxes. In line with existing research, we test these theories using the following set of proxy variables: dividend yield (DIV), profitability (PROF), research and development (RD), tangible assets (TANG), firm size (SIZE), capital expenditures (CAPEX), liquidity (LIQ), corporate tax rate (TAX), earnings volatility (EVOL), operational hedging $(\mathrm{OH})$, firm growth (GROW), and non-debt tax shield (NDTS). The corresponding hypothesis is:

\section{H3 The determinants of corporate hedging are responsible} for hedging decisions. 
In the same manner, the determinants of capital structure are integrated in our path model, in order to account for the two most prominent theories summarized as trade-off theory (Kraus \& Litzenberger, 1973) and pecking order theory (Myers, 1984), although various additional theories exist, such as market timing theory (Baker \& Wurgler, 2002), agency theory (Jensen \& Meckling, 1976), signalling theory (Ross, 1977), or free cash flow theory (Jensen, 1986). ${ }^{2}$ In line with previous research, we test the mentioned theories using the following set of proxy variables: DIV, PROF, RD, TANG, SIZE, CAPEX, LIQ, TAX, EVOL, GROW, and NDTS. The considerations above imply the following hypothesis:

\section{H4 The determinants of capital structure are responsible for corporate financing decisions.}

Finally, we follow relevant studies by Allayannis and Weston (2001), Carter et al. (2006), and Jin and Jorion (2006) and control for the direct impact of further potential explanatory factors of firm value (in particular DIV, PROF, RD, TANG, SIZE, and CAPEX), in addition to corporate hedging activities. ${ }^{3}$

H5 The determinants of firm value are responsible for changes in firms' market values.

\section{3 | META-ANALYSIS}

For our meta-analysis on the nexus between capital structure, corporate hedging, and firm value, we use previous empirical results, which we manually collected from existing primary studies. In the following, we describe the literature search procedure and the data preparation followed by a description of the meta-analytic calculations. The data search complies with the established guidelines published by the Meta-Analysis of Economics Research Network described by (Stanley et al., 2013).

\section{1 | Literature search}

We integrate reported results from two connected research strands: studies investigating the determinants of corporate hedging, as well as studies analyzing the determinants of capital structure. This combination of studies in our empirical meta-analysis is supported by the fact that most of the determinants of corporate hedging are also relevant for corporate capital structure (Aretz \& Bartram, 2010). Table 1 provides a detailed overview of the literature search process.
To identify the set of relevant studies, we perform literature searches in the two research fields mentioned above. During this literature search, we consider a study as relevant when it meets the following inclusion criteria. First, a study has to investigate non-financial firms, since financial companies act very differently, such that their hedging and capital structure decisions are fundamentally different and often part of their business model (e.g., they act as sellers of financial derivatives). Second, the study has to analyze corporate hedging activities (measured by a hedging dummy variable) or capital structure (measured by leverage ratio) as dependent variable, while considering the associated determinants as independent variables. Third, the study's sample size and a correlation matrix for the examined variables must be reported in the study. If a study reports more than one correlation table that is not based on the full sample, the corresponding (sub-)sample has to be reported for each correlation table.

For both strands of the literature, the search procedure consists of the following six steps, as summed up in Table 1, in order to cover the wide range of studies. First, we searched in four electronic databases for published literature: (a) ABI/INFORM Complete (including dissertations and theses), (b) Business Source Premier, (c) EconLit, (d) EconBiz, (e) GreenFILE, and (f) ScienceDirect. Second, we searched for gray literature via the Social Science Research Network (SSRN). Third, we performed a backward search in papers' reference lists. Fourth, we employed a forward search via the cited-byoption in Google Scholar. Fifth, we searched each author's publication list on their homepages and on Google Scholar for related articles. Finally, we exchanged correspondence with all authors of papers with missing information and requested the respective correlation tables.

Overall, 411 primary studies from the past 30 years provide relevant correlation data for our meta-analysis. A complete reference list of the study sample is available in the Online Data S1. The sample includes 116 unpublished articles (27.23\%). 158 studies investigate the determinants of corporate hedging, the remaining 253 studies analyze the determinants of corporate capital structure. The studies report 6,312 relevant results in the form of Pearson correlation coefficients (hereafter referred to as "effect size") based on a total of 2,572,731 firm observations.

\section{2 | Data preparation}

The study samples are checked for independence. In this regard, we follow Hunter and Schmidt (2004) and Stanley and Doucouliagos (2012) suggesting that two or more studies are assumed to be independent if different authors use the same/similar data set or if the same 
T A B L E 1 Literature search in electronic databases for corporate capital structure

\begin{tabular}{ll}
\hline Literature search process & Capital structure literature \\
\hline Inclusion criteria & \\
$\begin{array}{l}\text { 1. Appropriate definition of the variable of } \\
\text { interest }\end{array}$ & $\begin{array}{c}\text { Capital structure has to be analyzed as } \\
\text { dependent variable in the primary studies. }\end{array}$ \\
$\begin{array}{l}\text { 2. Appropriate data for effect-size } \\
\text { calculation }\end{array}$ & $\begin{array}{l}\text { The study contains sufficient information } \\
\text { about the correlation between capital }\end{array}$ \\
& $\begin{array}{l}\text { structure and the examined proxy } \\
\text { variables or/and the correlations among } \\
\text { the proxy variables themselves. }\end{array}$ \\
\hline
\end{tabular}

3. Extractable sample size

4. Only non-financial firms
The study's sample size must be extractable for each correlation table in order to calculate the effect size variation and the study weight.

The study investigates non-financial firms. However, we do not exclude studies containing both financial and nonfinancial firms, if the sample was taken from a broad stock market index.

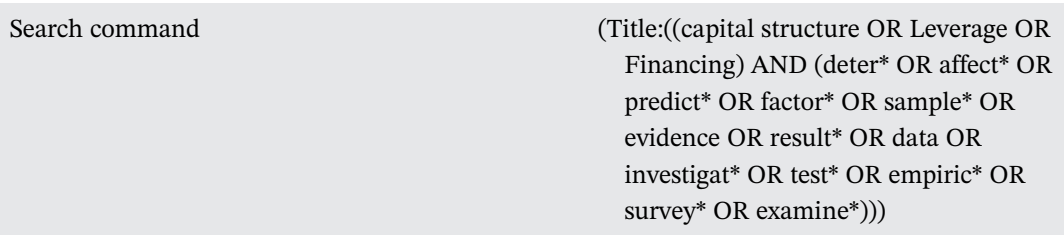

(n)

(n)

(Title:((capital structure OR Leverage OR Financing) AND (deter* OR affect* OR predict* OR factor* OR sample* OR evidence OR result* OR data OR investigat* OR test* OR empiric* OR survey* OR examine*)))

Hedging literature

The hedging decision has to be analyzed as dependent variable in the primary studies.

The study contains sufficient information about the correlation between the hedging dummy and the examined proxy variables or/and the correlations among the proxy variables themselves. Otherwise, there must be sufficient data from the descriptive statistics (e.g., t-statistic from a test with independent groups or the standardized mean difference between the hedgers and non-hedgers group) to replicate the correlations according to accepted conversions (Borenstein 2009).

The study's sample size must be extractable for each correlation table in order to calculate the effect size variation and the study weight.

The study investigates non-financial firms. However, we do not exclude studies containing both financial and nonfinancial firms, if the sample was taken from a broad stock market index.

(All Fields: hedg* OR derivative* AND All Fields: use OR using OR usage OR polic* OR activit* AND All Fields: compan* OR corporat* OR firm AND All Fields: sample OR evidence OR result* $\mathrm{OR}$ data $\mathrm{OR}$ investigat* OR test* OR empiric* OR survey* OR examine*)

Language: English, German

Date range: until June 24, 2014

Peer reviewed, working papers (SSRN)

Peer reviewed, working papers (SSRN)

\begin{tabular}{|c|c|c|}
\hline Search results & 2,022 & 3,814 \\
\hline Relevant after content check & 474 & 91 \\
\hline \multicolumn{3}{|l|}{ Further steps } \\
\hline $\begin{array}{l}\text { 2. Additionally relevant studies from } \\
\text { forward search }\end{array}$ & 141 & 32 \\
\hline $\begin{array}{l}\text { Total number of relevant studies } \\
\text { without duplicates }\end{array}$ & 591 & 167 \\
\hline
\end{tabular}

Note: The table presents the details of the literature search procedure. First, the inclusion criteria for the literature search are defined. Further, the individual search command as well as the search options are listed. Afterwards, the numbers of search results are noted together with the numbers of remaining studies after checking the title in a first iteration and the content check in a second iteration. Based on the relevant studies, a backward search, a forward search, as well as a check of the author's publication lists (for authors who wrote more than one relevant study) are performed. The corresponding numbers are given below. The last row shows the total number of primary studies integrated in the analysis of the study at hand. 
authors use different data sets. Consequently, we had to exclude three studies investigating the determinants of corporate hedging due to dependent data sets. If studies use an identical sample of firms, we use each proxy variable from this sample only once. ${ }^{4}$ However, we do not control for overlapping samples across studies, as the aim of meta-analysis is to aggregate propositions made in primary studies. Although studies might have overlapping samples (e.g., when they are examining the same country and similar time periods), each study reports an individual result due to study-specific variable definitions, individual data preparation, ${ }^{5}$ and different data sources.

One requirement for the choice of variables used in our meta-analysis is that each bivariate effect among the integrated variables has to be observed at least once in the sample of primary studies. Hence, our analysis is limited to the greatest possible set of variables for which this condition is fulfilled. Table 2 presents the set of included variables with the respective definitions and abbreviations. On average, each mean correlation is calculated based on a set of 47 primary studies and 215,427 firm observations.

From each of the 411 studies, we manually collected the correlation matrices for capital structure decisions, hedging decisions, and their interactions with other firm characteristics. Moreover, we extracted the corresponding sample sizes. Although all the studies in the sample empirically investigate capital structure and hedging decisions, the study designs and data sets examined vary widely. To account for this heterogeneity, we also extracted the time period, countries under examination, the publication status of the paper and other study characteristics reported in Table 3.

\section{3 | HOMA procedure}

To aggregate the collected effect sizes for the relations between each of the endogenous variables in our path model (LEV, DH, and FV) and its predictors, we compute normally-distributed mean effect sizes using Hedges and Olkin-type meta-analysis (HOMA; Hedges \& Olkin, 1985). The same methodology is used for moderator analysis and is applied to several subgroups of the data.

From the $i$-th study included in our sample, we use the correlation coefficient $r_{i}$ for the respective bivariate relation as input for the calculations. The mean effect size for a bivariate relation and its $S D$ is consequently calculated by

$$
\bar{r}=\frac{\sum\left(w_{i} \times r_{i}\right)}{\sum w_{i}} \text { with } S E(\bar{r})=\sqrt{\frac{1}{\sum w_{i}}},
$$

where $w_{i}$ is the weight of the $i$-th correlation coefficient calculated by the inverse variance of $r_{i}$. Consequently, the mean effect size $\bar{r}$ accounts for differences in precision and, hence, study quality by assigning study-specific weights to each observation in a transparent, objective, and replicable way (Borenstein, 2009). More precise observations receive higher weights in meta-analysis.

In order to achieve normally distributed effect sizes, we use Fisher's $z$-transformation to correct for skewness in $r_{i}$. Consequently, the $z$-transformed effect sizes are calculated by

$$
z_{i}=0,5 * \ln \left(\frac{1+r_{i}}{1-r_{i}}\right) \text { and } \operatorname{SE}\left(z_{i}\right)=\frac{1}{\sqrt{n_{i}-3}},
$$

where $n_{i}$ is the number of firms associated with $r_{i}$.

To account for unobserved heterogeneity in the effect sizes, we apply the random effects meta-analysis model. In essence, effect sizes are assumed to vary due to a study-specific sampling error covered by the variance of the effect size as well as due to randomly distributed sources of heterogeneity, denoted by a random effects component $\tau^{2}$. The random effects weights are then calculated by the inverse sum of these two components. ${ }^{6}$

\section{4 | MASEM procedure}

Further, we employ MASEM to test the structural equations of the path model (Cheung \& Chan, 2005; Viswesvaran \& Ones, 1995). The general idea is to use a set of reported Pearson product-moment correlation tables to calculate a full meta-analytic pooled correlation matrix by estimating separate mean effect sizes for each bivariate relationship using the HOMA procedure presented above.

The parameters of interest are estimated in the form of a matrix A incorporating the structural parameters between the variables, a matrix $\mathrm{S}$ contains the variances and covariances among the variables, and a matrix $\mathrm{F}$ used to select the observed variables (Jak, 2015). The general model can be written as follows, for example for a hypothetical model in the four variable case:

$$
\begin{aligned}
\boldsymbol{A}= & {\left[\begin{array}{cccc}
0 & 0 & 0 & 0 \\
0 & 0 & 0 & 0 \\
\beta_{31} & \beta_{32} & 0 & 0 \\
0 & 0 & \beta_{43} & 0
\end{array}\right], \mathbf{S}=\left[\begin{array}{cccc}
\psi_{11} & \psi_{12} & 0 & 0 \\
\psi_{21} & \psi_{22} & 0 & 0 \\
0 & 0 & \psi_{33} & 0 \\
0 & 0 & 0 & \psi_{44}
\end{array}\right], } \\
& \text { and } \boldsymbol{F}=\left[\begin{array}{llll}
1 & 0 & 0 & 0 \\
0 & 1 & 0 & 0 \\
0 & 0 & 1 & 0 \\
0 & 0 & 0 & 1
\end{array}\right] .
\end{aligned}
$$

$\beta_{31}$, for example, measures the effect of variable 3 on variable 1 , while $\psi_{12}$ is the covariance between variable 1 
TABLE 2 Variable description

\begin{tabular}{|c|c|c|}
\hline Variable & Abbrev & Description \\
\hline \multicolumn{3}{|c|}{ Endogenous variables } \\
\hline \multicolumn{3}{|l|}{ Firm value measure } \\
\hline Firm value & FV & $\begin{array}{l}\text { (Logarithm of) Market value of } \\
\text { firm } \div \text { book value of total } \\
\text { assets }\end{array}$ \\
\hline \multicolumn{3}{|c|}{ Corporate hedging measure } \\
\hline Decision to hedge & $\mathrm{DH}$ & $\begin{array}{c}=1 \text { if a firm applies corporate } \\
\text { hedging via financial } \\
\text { derivatives, } 0 \text { otherwise }\end{array}$ \\
\hline \multicolumn{3}{|c|}{ Capital structure measure } \\
\hline Leverage ratio & LEV & $\begin{array}{l}\text { Book value of long-term or total } \\
\text { debt (scaled) }\end{array}$ \\
\hline \multicolumn{3}{|l|}{ Exogenous variables } \\
\hline Dividend yield & DIV & Dividend per share (scaled) \\
\hline Profitability & PROF & $\begin{array}{l}\text { (Logarithm of) Sales or return } \\
\text { on assets or EBIT (scaled) }\end{array}$ \\
\hline $\begin{array}{l}\text { Research and } \\
\text { development }\end{array}$ & $\mathrm{RD}$ & $\begin{array}{l}\text { Research and development } \\
\text { expenses (scaled) }\end{array}$ \\
\hline Tangible assets & TANG & Tangible assets (scaled) \\
\hline Size & SIZE & $\begin{array}{l}\text { (Logarithm of) Book value of } \\
\text { total assets or market value of } \\
\text { the firm }\end{array}$ \\
\hline Capital expenditures & CAPEX & Capital expenditures (scaled) \\
\hline Liquidity & LIQ & $\begin{array}{l}\text { Current assets or cash and cash } \\
\text { equivalents (scaled) }\end{array}$ \\
\hline Tax rate & TAX & Marginal tax rate \\
\hline Earnings volatility & EVOL & $\begin{array}{l}S D \text { of earnings before interest } \\
\text { and taxes, return on assets } \\
\text { respectively }\end{array}$ \\
\hline Operational hedging & $\mathrm{OH}$ & $\begin{array}{l}\text { (Logarithm of) the absolute } \\
\text { amount of geographical or } \\
\text { industrial diversification }\end{array}$ \\
\hline Growth & GROW & Yearly turnover growth (scaled) \\
\hline Non-debt tax shield & NDTS & $\begin{array}{l}\text { Depreciation plus amortization } \\
\text { (plus investment tax credits } \\
\text { and tax loss carryforwards) } \\
\text { (scaled) }\end{array}$ \\
\hline
\end{tabular}

Note: This table sums up the proxy variables reviewed in the multivariate meta-analysis of this study, including the abbreviation. Our variable definitions arise from an aggregation of the variables in the reviewed studies and are similar to those of the meta-analyses by Aretz and Bartram (2010), Arnold et al. (2014), and GeyerKlingeberg et al. (2018). The descriptions are generalizations of the study-specific variable definitions.

and variable 2. Overall, eight free parameters must be estimated in the model in Equation (3) ( $\psi_{12}$ and $\psi_{21}$ is treated as one free parameter, since they are equal in value). The corresponding number of degrees of freedom is the difference between the number of observed (co-) variances minus the number of free parameters. The model-implied covariance matrix $(\boldsymbol{\Sigma}(\boldsymbol{\theta}))$ can be calculated as a function of these matrices

$$
\boldsymbol{\Sigma}(\boldsymbol{\theta})=(\boldsymbol{F}-\boldsymbol{A})^{-1} \boldsymbol{S}(\boldsymbol{F}-\boldsymbol{A})^{-1 T} .
$$

A better model fit is evaluated when the difference between the model-implied covariance matrix $\boldsymbol{\Sigma}(\boldsymbol{\theta})$ and the observed covariance matrix $\boldsymbol{\Sigma}(\hat{\boldsymbol{\theta}})$ is smaller. Therefore, the model parameters are estimated by minimizing a discrepancy function. As common in MASEM, the maximum-likelihood estimation is used (Cheung, 2015). Accordingly, the discrepancy function can be written as

$$
F_{M L}(\theta)=\log |\boldsymbol{\Sigma}(\boldsymbol{\theta})|-\log |\boldsymbol{\Sigma}(\hat{\boldsymbol{\theta}})|+\operatorname{tr}\left(\boldsymbol{\Sigma}(\hat{\boldsymbol{\theta}}) \mathbf{\Sigma}(\boldsymbol{\theta})^{-\mathbf{1}}\right)-p,
$$

where $p$ is the number of variables in the model. With an increasing model fit, the more $F_{M L}(\theta)$ converges towards zero (Jak, 2015).

We analyze the following system of equations according to the path model:

$$
\begin{aligned}
F V= & \beta_{1} D H+\beta_{2} L E V+\beta_{3} D I V+\beta_{4} P R O F+\beta_{5} R D \\
& +\beta_{6} T A N G+\beta_{7} S I Z E+\beta_{8} C A P E X+\epsilon_{T Q}, \\
D H= & \beta_{9} D I V+\beta_{10} P R O F+\beta_{11} R D+\beta_{12} T A N G+\beta_{13} S I Z E \\
& +\beta_{14} C A P E X+\beta_{15} L I Q+\beta_{16} T A X+\beta_{17} E V O L \\
& +\beta_{18} O H+\beta_{19} G R O W+\beta_{20} N D T S+\epsilon_{D H}, \\
L E V= & \beta_{21} D H+\beta_{22} D I V+\beta_{23} P R O F+\beta_{24} R D+\beta_{25} T A N G \\
& +\beta_{26} S I Z E+\beta_{27} C A P E X+\beta_{28} L I Q+\beta_{29} T A X \\
& +\beta_{30} E V O L+\beta_{31} G R O W+\beta_{32} N D T S+\epsilon_{L E V} .
\end{aligned}
$$

When employing a pooled correlation matrix for MASEM, there are two main issues to consider. First, a single sample size has to be chosen for fitting the model. Following the consensus (among others, Carney et al., 2015; Cheung, 2015; Sheng, Kong, Cortina, \& Hou, 2016) and recommendations of recent publications (Landis, 2013), we use the harmonic mean of the across the aggregated numbers of firms in the pooled correlation matrix (as displayed in the upper triangular matrix of Table 5) as a conservative estimate. In our case, the 
T A B LE 3 Overview of data coded from the primary studies

\begin{tabular}{|c|c|}
\hline Variable & Description \\
\hline \multicolumn{2}{|l|}{ Effect size } \\
\hline$r_{i}$ & $\begin{array}{l}\text { Pearson correlation coefficients for the relation between one, several or all relation among the } \\
\text { variables defined in this table. }\end{array}$ \\
\hline$n_{i}$ & $\begin{array}{l}\text { The sample size covering the number of firms in the study sample used to estimate the correlation } \\
\text { coefficient } r_{i} \text {. }\end{array}$ \\
\hline \multicolumn{2}{|l|}{ Study characteristics } \\
\hline \multicolumn{2}{|l|}{ Publication characteristics } \\
\hline Published study & $=1$ if a study is published in a referred journal \\
\hline Unpublished study & $=1$ if a study is an unpublished working paper or book chapter \\
\hline \multicolumn{2}{|l|}{ Data characteristics } \\
\hline Mean year before 2000 & $=1$ if $[($ sample start year + sample end year $) \div 2]$ is before the year 2000 \\
\hline Mean year between 2000-2008 & $=1$ if $[($ sample start year + sample end year $) \div 2]$ is between the year 2000 and 2008 \\
\hline Mean year after 2008 & $=1$ if $[($ sample start year + sample end year $) \div 2]$ is after the year 2008 \\
\hline Single-industry sample & $=1$ if the study sample examines on specific industry \\
\hline Cross-sectional sample & $=1$ if the study sample examines data across multiple industries \\
\hline \multicolumn{2}{|l|}{ Regional differences } \\
\hline East Asia \& Pacific & $=1$ if a sample uses firm data from East Asia and the Pacific \\
\hline Europe \& Central Asia & $=1$ if a sample uses firm data from Europe and Central Asia \\
\hline Latin America \& Caribbean & $=1$ if a sample uses firm data from Latin America and the Caribbean \\
\hline Middle East \& North Africa & $=1$ if a sample uses firm data from Middle East and North Africa \\
\hline North America & $=1$ if a sample uses firm data from North America \\
\hline South Asia & $=1$ if a sample uses firm data from South Asia \\
\hline Sub-Saharan Africa & $=1$ if a sample uses firm data from sub-Saharan Africa \\
\hline \multicolumn{2}{|l|}{ Economic development ${ }^{\mathrm{a}}$} \\
\hline Developed country & $=1$ if a sample data refers to one or multiple developed countries \\
\hline Developing country & $=1$ if a sample data refers to one or multiple developing countries \\
\hline \multicolumn{2}{|l|}{ Law system ${ }^{\mathrm{b}}$} \\
\hline Civil law system & $=1$ if a sample data refers to one or multiple countries having a civil law legal system \\
\hline Non-civil law system & $\begin{array}{l}=1 \text { if a sample data refers to one or multiple countries having a common law or other non-civil law } \\
\text { system }\end{array}$ \\
\hline
\end{tabular}

Note: This table presents the variables coded from the set of primary studies.

a Data for this classification is taken from the Organization for Economic Co-operation and Development (OECD): https://www.oecd.org/ dac/stats/documentupload/DAC List of ODA Recipients 2014 final.pdf.

${ }^{\mathrm{b}}$ Data for the classification into common and civil law countries is taken from the World Factbook of the Central Intelligence Agency: https://www.cia.gov/library/publications/the-world-factbook/fields/2100.html.

harmonic mean number of firm observations is 3,661 . Alternatively, the arithmetic mean, the median, or the total sample size are discussed in literature (Cheung, 2015). However, the harmonic mean is judged to be the most conservative estimate (Landis, 2013). Second, following recent meta-analysis examples (among others, Hamari \& Keronen, 2017; Oort \& Jak, 2016), we decide to use unit $S D s$ in the MASEM calculations, which is necessary when treating the correlation matrix as a covariance matrix. For a detailed description of the MASEM calculations, see Cheung (2015) and Jak (2015).

\section{4 | PRESENTATION OF META- ANALYTICAL RESULTS}

In the following, we present the meta-analytical results derived from the HOMA and MASEM procedures. 


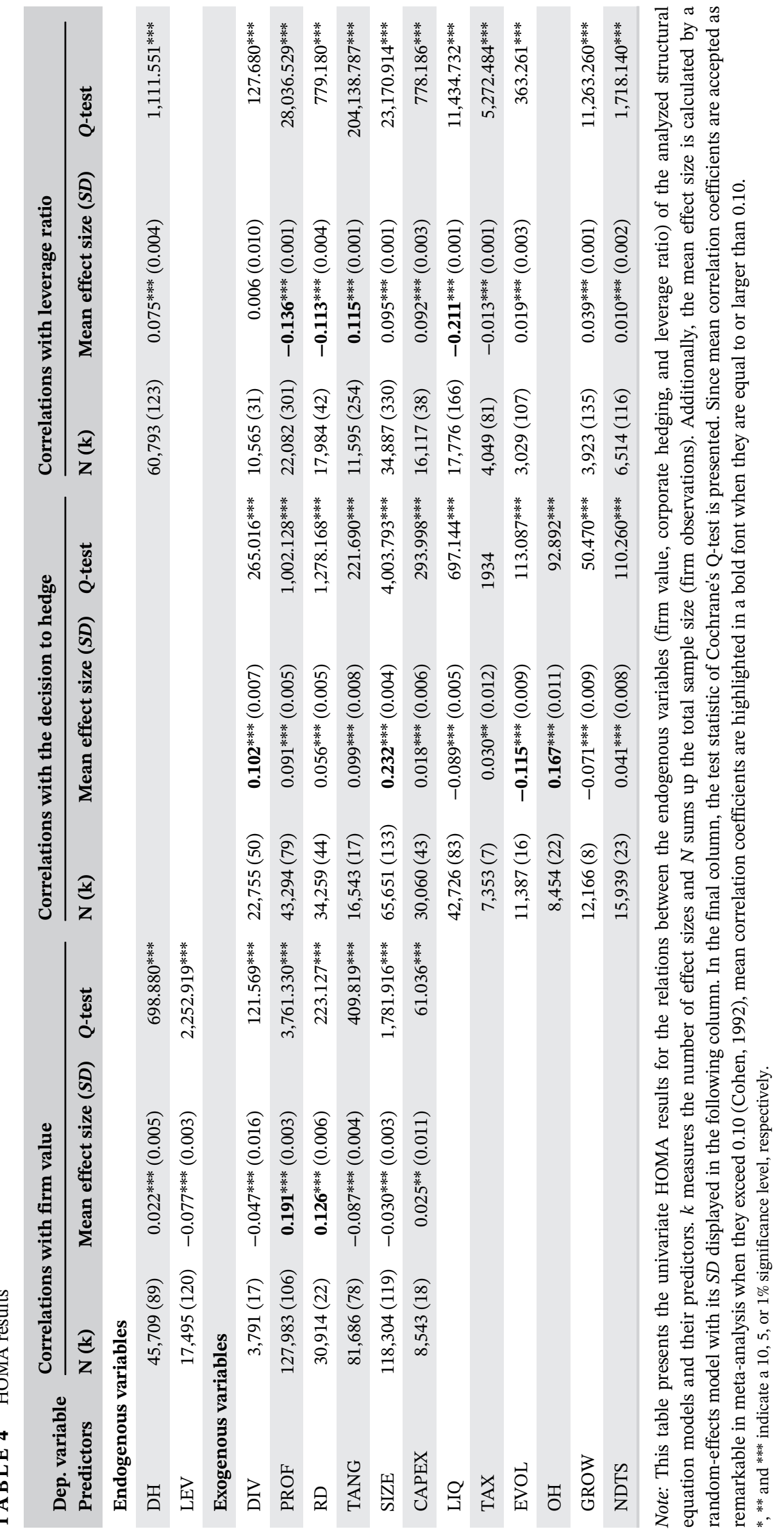




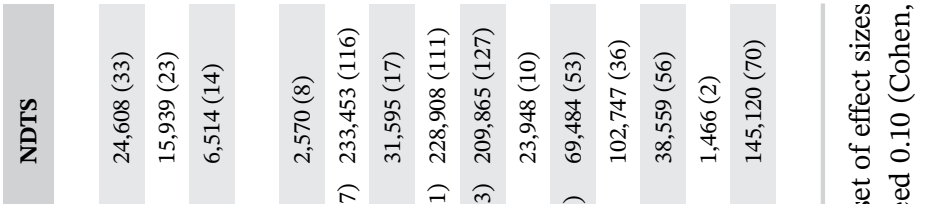

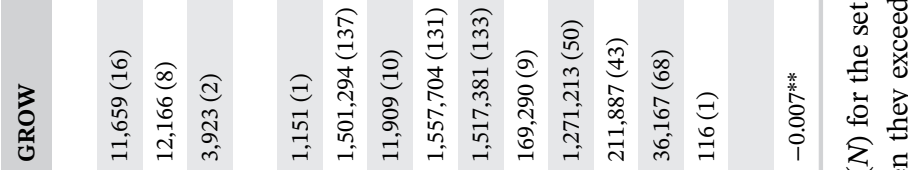

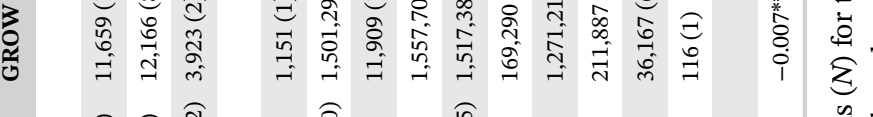

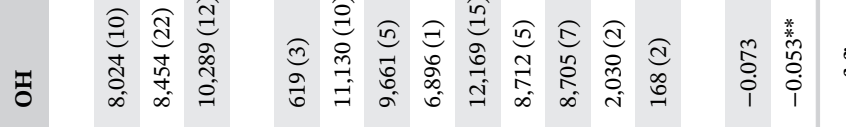

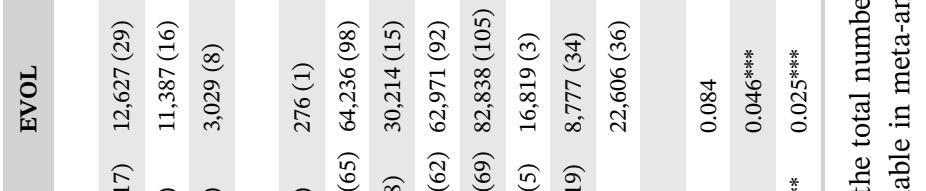

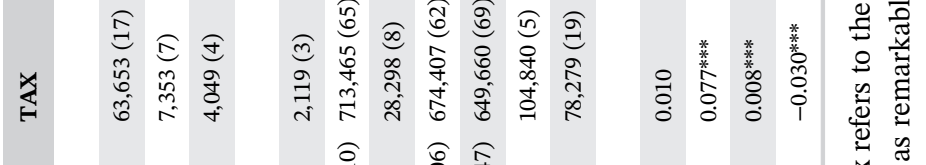

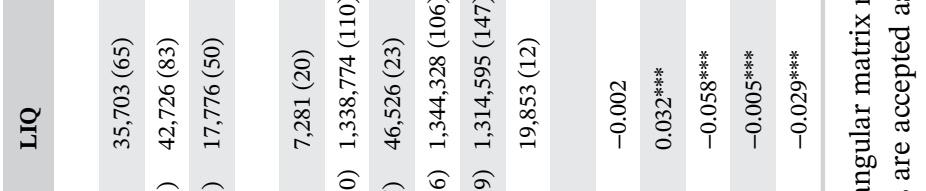

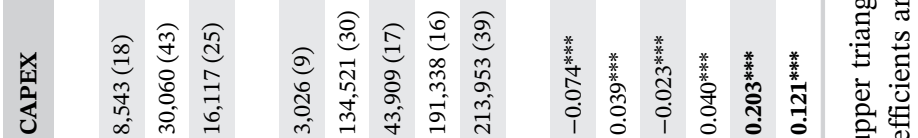

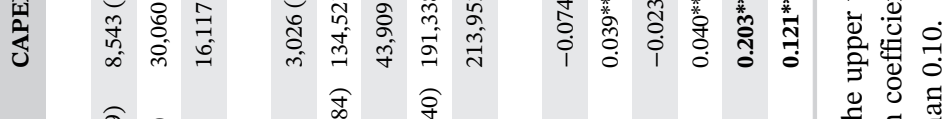

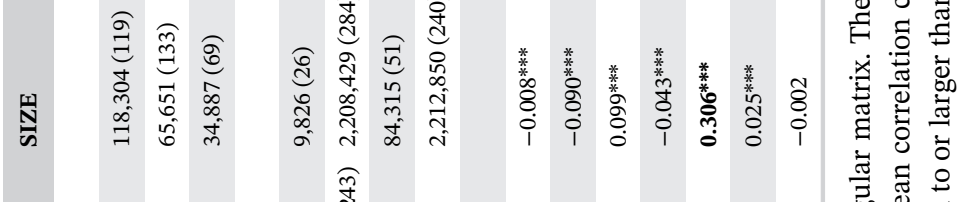

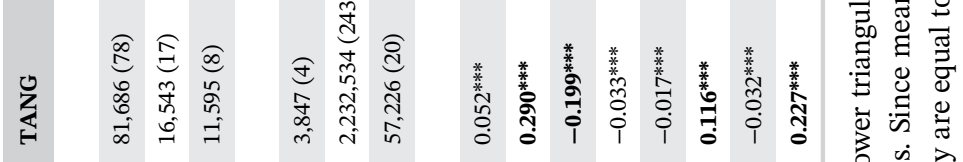

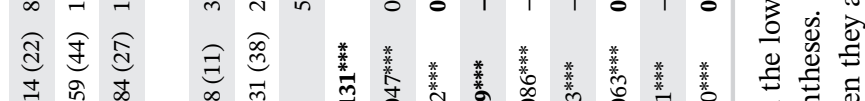

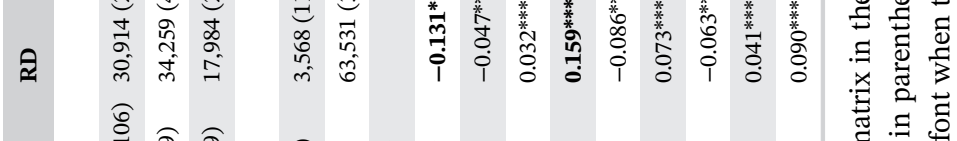

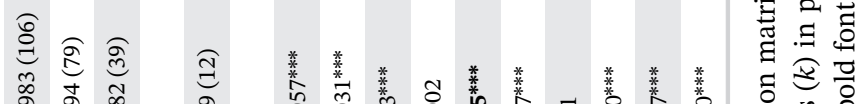

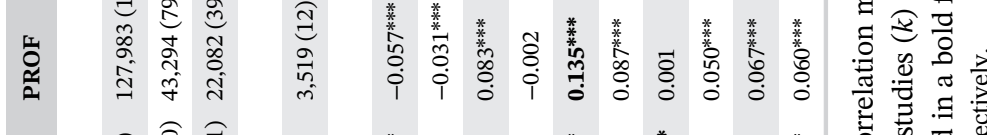

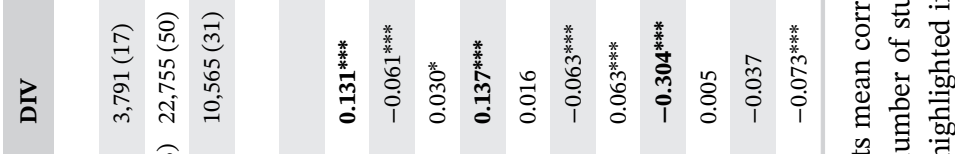

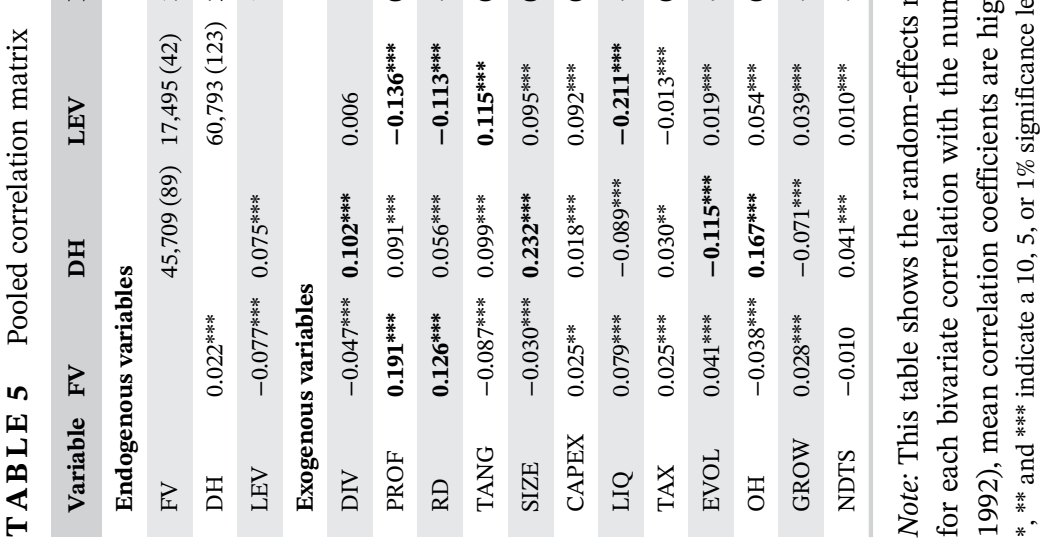


MASEM serves to test the central hypotheses $H 1, H 2 a$ and $H 2 b$. Further, we use HOMA to test the hypotheses $H 3$, $H 4$, and H5. Therein, we especially shed light on publication selection bias. Finally, we present results from the subgroup analyses used to investigate factors causing heterogeneity.

\section{1 | HOMA results}

Table 4 presents the univariate HOMA results. In particular, we analyze the factors affecting LEV, DH, and FV as formulized in the corresponding hypotheses $\mathrm{H} 3, \mathrm{H} 4$ and H5. ${ }^{7}$ First, referring to the effects of interest among the endogenous variables themselves (LEV, DH, and FV), we identify that LEV significantly depends on DH. The results show a mean effect size of 0.075 . Hence, we conclude that hedging activities lead to smoothed incomes, which in turn increase debt capacity (Graham \& Rogers, 2002). Moreover, DH shows a statistically significant relation to FV, with a mean effect size of 0.022 . Although the absolute effect is relatively small, the decision to hedge might have a constantly positive impact on firm value. Hence, our HOMA results verify previous findings by, among others, Allayannis and Weston (2001) and Carter et al. (2006). Consequently, investors might value the available knowledge for corporate hedging activities as well as smoothed earnings, independent from the amount of the hedging volume. Following Jin and Jorion (2006), we do not interpret the relation as an impact of firm value on corporate hedging, since variations in market values are not assumed to predict corporate hedging behaviour. Besides, the result for the relation between LEV and FV with a significant mean effect size of -0.077 implies that higher levels of debt financing increase costs of financing and bankruptcy due to more volatile earnings, which in turn lead to a decreasing firm value (Titman \& Wessels, 1988).

Second, we also investigate the determinants of LEV, $\mathrm{DH}$, and FV using HOMA, thus observing the main determinants of LEV as statistically significant mean effect sizes for the dependence of LEV on PROF (-0.136), RD (-0.113), TANG (0.115), and LIQ (-0.211). In the same way, we reveal DIV, SIZE, OH, and EVOL as the main determinants of DH. Furthermore, PROF and RD show the greatest mean effect sizes for the relation to $\mathrm{FV}$, with remarkable mean correlation coefficients of 0.191 for PROF and 0.126 for RD, both statistically significant at any significance level.

A summary of random effects mean effect sizes for all bivariate relations among the analyzed endogenous and exogenous variables is shown in Table 5 in the form of a pooled correlation matrix. This matrix later serves as input for the MASEM procedure.

\section{2 | MASEM results}

Before interpreting the results of the MASEM procedure in order to examine the hypotheses $H 1, H 2 a$, and $H 2 b$, we evaluate the model fit. Following standard SEM, we consult several test statistics simultaneously, in order to obtain a reliable assessment. As presented in Table 6, we use the following criteria to evaluate the goodness of fit: chi-square $\left(\chi^{2}\right)$, the comparative fit index (CFI), the root mean squared error of approximation (RMSEA), and the standardized root mean square residual (SRMR). The test statistics result in $\chi^{2}=56.82(d f=10)$, CFI $=0.95$, RMSEA $=0.04$, and SRMR $=0.02$. Applying the conventional limits from standard SEM allows us to conclude that the model fits the data well (Hu \& Bentler, 1999; Marsh, Kit-Tai, \& Zhong, 2004).

Starting with the MASEM results for the endogenous variables, it becomes apparent that there is no significant effect between DH and FV ( $\beta=0.019, t=1.185)$. In contrast to HOMA, hypothesis $H 1$ cannot be accepted, which might be due to the additional consideration of mediating effects. Thus, investors do not directly value corporate hedging activities as positive or negative. However, we reveal a significant mediating effect, in that $\mathrm{DH}$ has a statistically significant positive relation with LEV ( $\beta=0.066, t=3.994)$ in the first step of this indirect effect. In the second step of the mediating effect, we find that LEV has a negative relation with FV $(\beta=-0.031$, $t=-1.890)$. To evaluate the statistical significance of the mediating effects, we perform statistical tests following standard SEM procedure. The test results confirm the mediation function of LEV for the relation between DH and FV (Sobel test: $t=-1.754, p=0.079$; Aroian test: $t=-1.713, p=0.087$; Goodman test: $t=-1.797$, $p=0.072$ ). Hence, hypothesis $H 2 a$ as well as $H 2 b$ can be accepted. The result for the hedging-leverage link confirms the hypothesis developed by Graham and Rogers (2002), Leland (1998), and Stulz (1996), supporting a positive impact of corporate hedging activities on leverage ratio. This indicates that hedging is a means to increase debt capacity, and is thus in line with recent findings from, among others, Bartram et al. (2009), Haushalter (2000), and Pérez-González and Yun (2013). Additionally, the result for the leverage-firm value link points to the hypothesis proposed by Leland (1998), who states that distress costs decrease due to unused debt capacity. Hence, firms should not make use of the possibility to enhance the level of debt financing, due to the potential negative impact on firm value. Although this conclusion may seem contradictory at first, one might also regard these two identified relations as intuitive, since corporate hedging as well as (relatively) lower debt levels support lower-risk earnings expectations. Due to 


\begin{tabular}{|c|c|c|c|c|c|c|}
\hline \multirow{2}{*}{$\begin{array}{l}\text { Dep. variable } \\
\text { Predictors }\end{array}$} & \multicolumn{2}{|l|}{ FV } & \multicolumn{2}{|l|}{ DH } & \multicolumn{2}{|l|}{ LEV } \\
\hline & $\beta$ & $t_{\beta}$ & $\beta$ & $t_{\beta}$ & $\beta$ & $t_{\beta}$ \\
\hline \multicolumn{7}{|c|}{ Endogenous variables } \\
\hline $\mathrm{DH}$ & 0.019 & 1.185 & & & $0.066^{* * *}$ & 3.994 \\
\hline LEV & $-0.031^{*}$ & -1.890 & & & & \\
\hline \multicolumn{7}{|l|}{ Exogenous variables } \\
\hline DIV & $-0.063^{* * *}$ & -3.710 & $0.030^{*}$ & 1.699 & 0.005 & 0.293 \\
\hline PROF & $0.200^{* * *}$ & 11.772 & $0.089^{* * *}$ & 5.179 & $-0.134^{* * *}$ & -7.780 \\
\hline $\mathrm{RD}$ & $0.116^{* * *}$ & 6.871 & $0.109^{* * *}$ & 6.356 & $-0.100^{* * *}$ & -5.786 \\
\hline TANG & $-0.074^{* * *}$ & -4.193 & $0.072^{* * *}$ & 3.912 & $0.039^{* *}$ & 2.131 \\
\hline SIZE & $-0.030^{*}$ & -1.765 & $0.178^{* * *}$ & 10.068 & $0.073^{* * *}$ & 4.230 \\
\hline CAPEX & $0.047^{* *}$ & 2.692 & -0.006 & -0.324 & $0.065^{* * *}$ & 3.652 \\
\hline LIQ & & & $-0.076^{* * *}$ & -4.409 & $-0.153^{* * *}$ & -8.785 \\
\hline TAX & & & 0.009 & 0.512 & -0.022 & -1.298 \\
\hline EVOL & & & $-0.109^{* * *}$ & -6.215 & $0.044^{* *}$ & 2.494 \\
\hline $\mathrm{OH}$ & & & $0.107^{* * *}$ & 5.998 & & \\
\hline GROW & & & $-0.069^{* * *}$ & -4.002 & $0.040^{* *}$ & 2.368 \\
\hline NDTS & & & 0.018 & 1.061 & 0.002 & 0.125 \\
\hline$\chi^{2}(d f)$ & $56.82(10)$ & & & & & \\
\hline $\mathrm{CFI}$ & 0.95 & & & & & \\
\hline RMSEA & 0.04 & & & & & \\
\hline SRMR & 0.02 & & & & & \\
\hline$N$ (harmonic mean) & 3,661 & & & & & \\
\hline
\end{tabular}

T A B L E 6 MASEM results

Note: This table presents the model statistics from meta-analytic structural equation modelling.

*,** and ${ }^{* * *}$ indicate a 10,5 , or $1 \%$ significance level, respectively.

the different signs of the two coefficients, the indirect effect of DH on FV can be seen as a suppression effect. Hence, there is no directly identifiable effect that explains the occurrence of insignificant findings from regression analysis in primary research (Jin \& Jorion, 2006). For the alternative direct effect of $\mathrm{DH}$ on $\mathrm{FV}$, our results do not show any statistically significant relation $(\beta=0.019$, $t=1.185$ ). This result contradicts the findings by, among others, Allayannis and Weston (2001), Clark and Judge (2009), and Pérez-González and Yun (2013), who observe a significant direct effect of corporate hedging activities on firm value. Thus, our results confirm an overall mediating effect. ${ }^{8}$

For a complete understanding of the meta-analytic results, we further calculate the total effects of all analyzed variables on firm value. Table 7 sums up the estimates of the total effects. As the results show, there are two dominating effects. First, PROF is revealed to be the main driver of FV with a significant total effect of 0.201 . Second, RD with a significant total effect of 0.118 might be seen as an indicator of future growth opportunities. Overall, firms are assumed to be valued by investors on the basis of these two variables. Conversely, firms that aim to maximize their firm value should increase their profitability and future growth opportunities as a firstorder concern.

\subsection{Analysis of heterogeneity}

As a further important result of the HOMA procedure, we observe highly significant $Q$-statistics as displayed in Table 4, which measure the amount of residual heterogeneity. Since most $Q$-statistics are statistically significant at any significance level, we suppose multiple factors are responsible for variations in the effect estimates reported in primary studies. In the following, we analyze the heterogeneity for the relations among the endogenous variables (LEV, DH, and FV), which are integrated in our path model. As is common in meta-analysis, we start with testing for the existence of a potential publication selection bias, typically performed in meta-analysis. This bias refers to a phenomenon in meta-analysis that authors prefer specific estimates and estimates deviating 
T A B L E 7 Total effects on firm value

\begin{tabular}{|c|c|c|c|}
\hline \multirow{2}{*}{$\begin{array}{l}\text { Dep. variable } \\
\text { Predictors }\end{array}$} & \multicolumn{3}{|l|}{ FV } \\
\hline & $\beta_{\text {total }}$ & $t_{\beta t o t a l}$ & $p$-value \\
\hline \multicolumn{4}{|c|}{ Endogenous variables } \\
\hline $\mathrm{DH}$ & 0.017 & 1.063 & 0.298 \\
\hline LEV & $-0.031^{*}$ & -1.890 & 0.059 \\
\hline \multicolumn{4}{|c|}{ Exogenous variables } \\
\hline DIV & $-0.062^{* * *}$ & -3.683 & 0.000 \\
\hline PROF & $0.201^{* * *}$ & 11.889 & 0.000 \\
\hline $\mathrm{RD}$ & $0.118^{* * *}$ & 7.005 & 0.000 \\
\hline TANG & $-0.073^{* * *}$ & -4.139 & 0.000 \\
\hline SIZE & -0.027 & -1.618 & 0.106 \\
\hline CAPEX & $0.047^{* * *}$ & 2.686 & 0.007 \\
\hline LIQ & 0.001 & -1.033 & 0.302 \\
\hline TAX & 0.000 & 0.461 & 0.645 \\
\hline EVOL & 0.002 & 1.047 & 0.295 \\
\hline $\mathrm{OH}$ & -0.002 & -1.048 & 0.295 \\
\hline GROW & -0.001 & -1.027 & 0.304 \\
\hline NDTS & 0.000 & 0.751 & 0.453 \\
\hline
\end{tabular}

Note: This table presents the calculated total effects on firm value (sum of direct plus indirect effects) of the analyzed variables. The values are calculated for the path model of the decision to hedge based on the corresponding MASEM results.

$*, * *$ and ${ }^{* * *}$ indicate a 10,5 , or $1 \%$ significance level, respectively.

from these are systematically underrepresented in empirical literature (Rosenthal, 1979). If, for example, literature largely agrees on the sign and significance of a certain determinant following an accepted theory, publication selection might cause an over-representation of larger and more significant confirming effects, leading to a distorted comprehension of the available literature (Card \& Krueger, 1995; Doucouliagos \& Stanley, 2013). To analyze the presence of publication selection bias, we apply a graphical investigation via funnel plots as standardly applied in meta-analysis (Stanley \& Doucouliagos, 2012). Therein, the effect sizes $(r)$ are plotted against their precision (1/SE $(r)$ or sample size). Figure 2 shows funnel plots of the effect sizes measuring the relations among the endogenous variables, which are integrated in our analytical models. In general, funnel plots are able to reveal the two existing types of publication bias (Stanley, 2005). If authors prefer to publish significant estimates with a particular direction, the funnel would be overweighted on one side (type I publication bias). If authors prefer to publish significant estimates independent of their direction, the funnel would be hollow due to missing insignificant estimates and unreasonably wide (type I publication bias). An unbiased sample should lead to a symmetrically inverted funnel, meaning that deviations of the single effect sizes from their mean value decrease with an increasing precision of estimation. The funnel plots in our case do not seem to speak for an existing obvious publication selection bias, since the effect sizes are generally symmetrically distributed in a funnel form. The funnel asymmetry (type II bias) is also checked by the socalled Egger-test (Egger, Smith, Schneider, \& Minder, 1997), which statistically checks the relation between $r$ and 1/SE( $r)$ and is commonly applied in metaanalysis (see, among others, Stanley \& Doucouliagos, 2012). Analogous to the visual impression, the test does not reveal any publication bias. ${ }^{9}$

In order to test the impact of further potential influencing factors, we perform several subgroup analyses. Table 8 shows the associated results, where $Q_{B}$ measures the between-group heterogeneity. First, we analyze if published studies report effect size estimates differing from those of unpublished studies. Except for the relation between FV and $\mathrm{DH}$, we observe statistically significant differences. In detail, unpublished studies report larger positive effect estimates for the relation between LEV and $\mathrm{DH}\left(Q_{B}=33.439\right)$. In contrast, published studies report larger negative effect estimates for the relation between FV and LEV $\left(Q_{B}=3,707.089\right)$. Consequently, unpublished studies contain additional information, which should be integrated to derive general conclusions, following the advice of Stanley and Doucouliagos (2012).

Furthermore, we analyze data characteristics, particularly temporal effects and differences between single-industry and cross-sectional samples. When comparing the time periods before 2000, between 2000 and 2008, and after 2008, we observe the following temporal developments. The mean effect size for the relation between FV and DH $\left(Q_{B}=49.187\right)$ decreases over time, starting with a positive value before 2000 , and ending with a negative value after 2008. In contrast, the relation between LEV and DH $\left(Q_{B}=61.152\right)$ increases across the time periods with a remarkable mean effect size of 0.186 in the period after 2008. For the relation between FV and LEV $\left(Q_{B}=2,278.698\right)$, the mean effect size becomes more negative over time, with an exceptional mean effect size of -0.176 for the period after 2008. Consequently, in recent years investors have begun to consider hedging activities as well as higher levels of external financing as more negative indicators of firm value. In contrast, an increase in debt capacity due to hedging activities has strongly emerged. Regarding the studies' sample compositions, we reveal significant differences between single-industry and cross-sectional samples for the relations between $\mathrm{FV}$ and $\mathrm{DH}$ $\left(Q_{B}=12.205\right)$ and between FV and $\operatorname{LEV}\left(Q_{B}=383.118\right)$. Consequently, industrial effects exist, which affect the 
Funnel plots
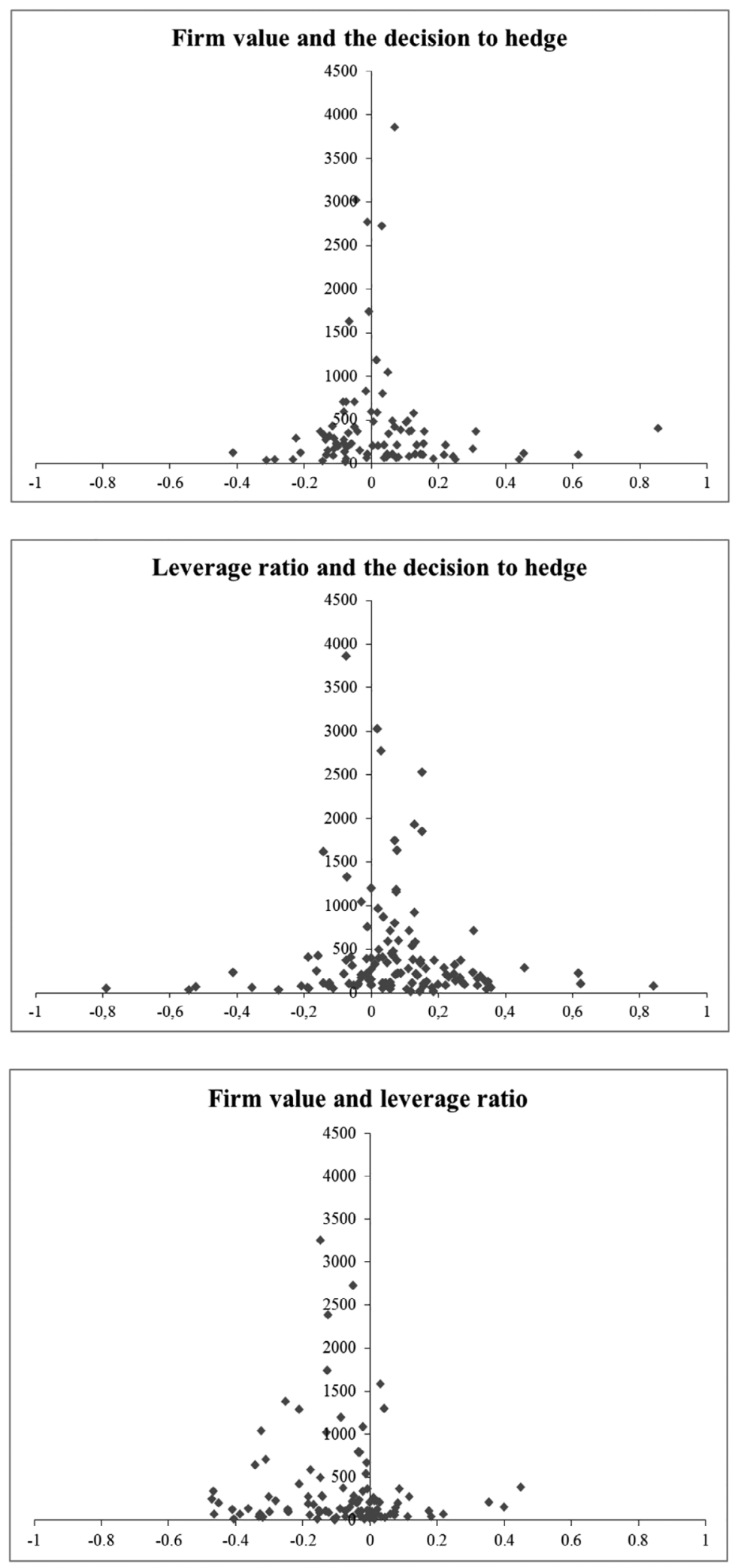

F I G U RE 2 Funnel plots. This tables presents the funnel plots for the relations among corporate hedging (DH), leverage ratio (LEV), and firm value (FV). The $z$ transformed effect sizes (correlation coefficients) are plotted against their precision (inverse $S E$ ) relations among our endogenous variables, especially the relations involving capital structure. Reasons for this might be industrial differences in the costs of financial distress (Bradley, Jarrell, \& Kim, 1984), agency costs (Hall,
Hutchinson, \& Michaelas, 2010), or asymmetric information (Myers, 1984).

When comparing the mean effect sizes among our endogenous variables for various geographic regions, we 


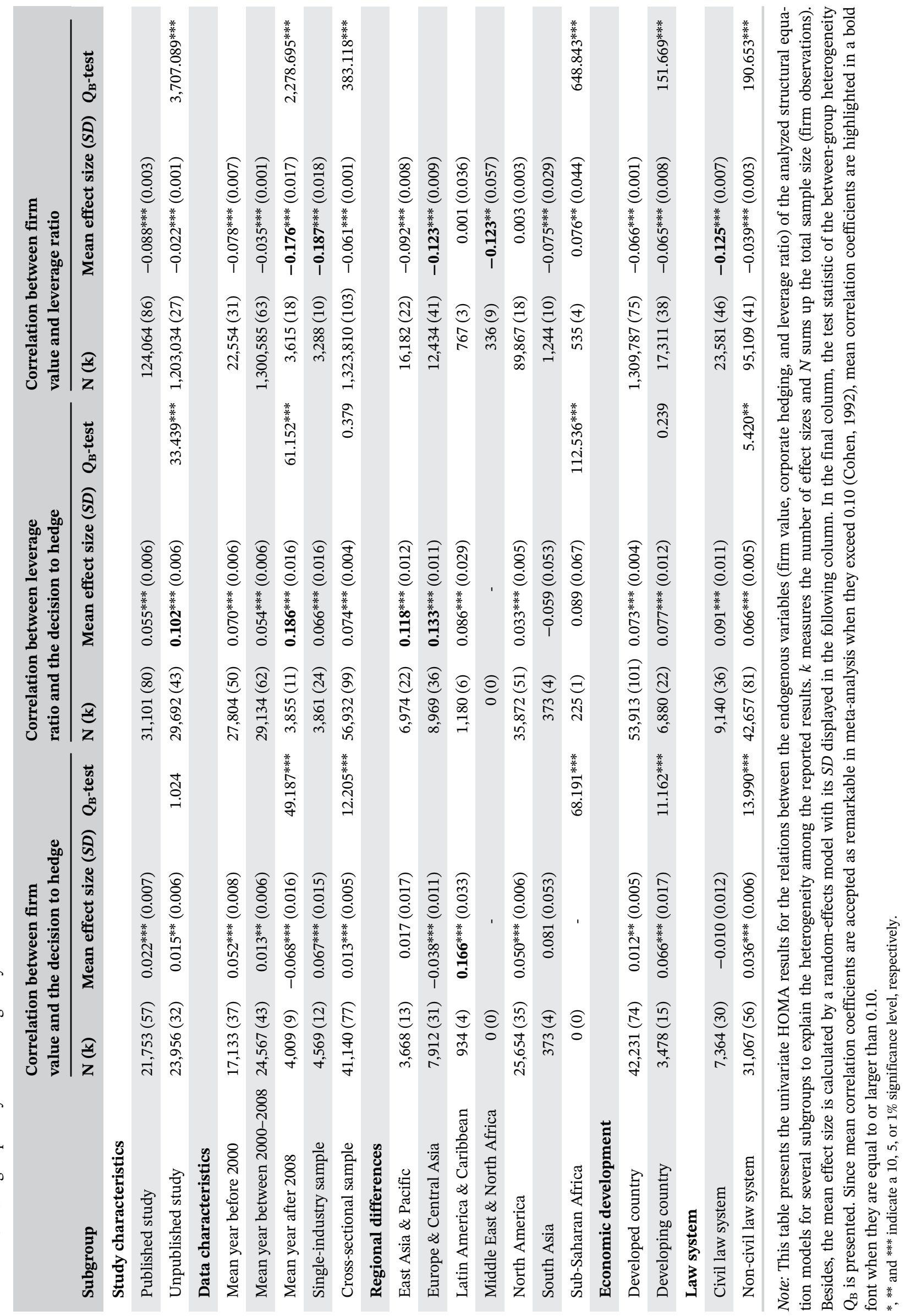


observe deviations for the relations between $\mathrm{FV}$ and $\mathrm{DH}$ $\left(Q_{B}=68.191\right)$, LEV and DH $\left(Q_{B}=112.536\right)$, and FV and $\operatorname{LEV}\left(Q_{B}=648.843\right)$. This result indicates that cross-country differences drive the mentioned effects. In addition to common cross-country differences, other factors may play a role, such as macroeconomic, political or legal differences, cultural differences (Chui, Lloyd, \& Kwok, 2002) or even consequences of globalization (Fernandes, 2011).

To study the influence of a country's economic development, we further split our sample into developed and developing countries. For the relation between FV and $\mathrm{DH}\left(Q_{B}=11.162\right)$, the difference between the subgroupspecific mean effect sizes is statistically significant. This result implies that market valuation of hedging activities seems to differ between developed and developing countries. In detail, the decision to hedge increases firm values in developing countries (with a mean effect size of 0.066) more than in developed countries (0.012). This observation might be reasoned by higher political and market risks in developing countries (Bartram et al., 2009). According to Fernandes (2011), differences in financial decisions will, however, disappear over time and the mean effect sizes will converge since globalization contributes to economic integration and helps to overcome domestic limitations of firms located in developing countries.

Finally, we test the impact of different legal systems. Differences among the mean effect sizes for civil law and non-civil law countries exist for the relations between FV and $\mathrm{DH}\left(Q_{B}=13.990\right)$, LEV and $\mathrm{DH}\left(Q_{B}=5.420\right)$, and $\mathrm{FV}$ and $\mathrm{LEV}\left(Q_{B}=190.653\right)$. Consequently, differences in jurisdiction and regulation also affect the nexus among $\mathrm{FV}, \mathrm{DH}$, and LEV, since a country's legal environment is assumed to affect corporate debt policies (Bancel \& Mittoo, 2004; Bortolotti, Cambini, Rondi, \& Spiegel, 2011; Cambini \& Spiegel, 2016) as well as incentives to hedge (Aretz \& Bartram, 2010).

\section{4 | Discussion}

Based on our results, we are able to derive several conclusions for economic theory as well as corporate decisionmaking.

\subsection{1 | Economic implications}

Starting with the HOMA results for the determinants of capital structure, the impacts of PROF (negative), RD (negative), TANG (positive), and LIQ (negative) on LEV consistently point to the pecking order theory (Myers \& Majluf, 1984). Consequently, our results imply that the costs of financing increase by the degree of information asymmetry. This finding is consistent with results from the MASEM procedure. Continuing with the HOMA results for the determinants of corporate hedging, the effects of DIV (positive), PROF (positive), and LIQ (negative) point to the costs of bankruptcy and financial distress hypothesis (Smith \& Stulz, 1985). Thus, corporate hedging activities are assumed to lower cash flow volatility (and therefore also the default probability), which reduces expected costs of financial distress and adds value to the firm. In the same manner, RD (positive) and TANG (positive) support the coordination of financing and investment and the agency conflicts of debt hypothesis. Hence, a reduced cash flow variability increases the probability of shareholders being the residual owners after reimbursing the bondholders and coordinates the availability of internal funds (Loss, 2012). Further, hedging lowers project risks and accordingly diminishes agency costs arising from the managerial incentive of asset substitution. These findings correspond with our MASEM results and the findings from previous research (Aretz \& Bartram, 2010; Arnold et al., 2014; GeyerKlingeberg et al., 2018). Overall, we find no evidence for tax incentives influencing capital structure or hedging decisions.

Keeping the above conclusions in mind allows for consistent interpretation of the results for the relations among the endogenous variables. Regarding the positive impact on LEV from DH, we conclude that firms might make use of this effect particularly via unused debt capacities. If a firm would in contrast extend debt financing due to increased debt capacities, this would lead to increasing tax benefits but also to increasing costs of bankruptcy and financial distress. This would contradict the results for the determinants of capital structure and corporate hedging, since we find no evidence for tax effects but rather for the motivation of firms to minimize the costs of bankruptcy and financial distress. Consequently, we conclude that firms might especially profit from unused debt capacity (Leland, 1998). Analogously, for the negative relation between LEV and FV, we further conclude that internal funds should be preferred against debt financing. By lowering earnings volatility, corporate hedging further increases the possibility of available internal funds and of the shareholders being the residual owner after satisfying bondholder claims (Froot et al., 1993). Hence, our results concerning the mediating role of capital structure are fully in line with the work by Gilje and Taillard (2017) who state that corporate hedging especially serves to reduce potential bankruptcy and underinvestment risks. Following the concept of shareholder value maximization, these financial resources should be used to enhance profitability and research and 
development activity. Overall, our results explain the decision to hedge primarily as a means to coordinate financing and investment decisions, which thereby reduces distress costs resulting from unused debt capacity and enhances a firm's profitability as well as value, by providing additional internal funds to realize profitable projects and future growth opportunities.

\subsection{2 | Limitations}

Although, the strength of MASEM is to replicate existing analyses and to test various hypotheses on data reported by prior studies, including correlations and sample sizes (Jak, 2015). However, the dependency on existing data also limits the conclusions of results produced by this methodology. Hence, the interpretation of MASEM coefficients as causal effects is only possible at the same level as in prior studies. Here, more primary studies are necessary using lagged versions of the latent variables, which would enhance the interpretability of the interaction effects in terms of the endogeneity problem.

Beyond the applied univariate version of MASEM, two alternatives exist: the multivariate (GLS) MASEM and the two-stage SEM (TTSEM). Although, the latter two versions dominate the univariate version by their statistical properties, the univariate version is applied in this study as the most widely spread version for the following reasons. First, the GLS approach requires that the variables integrated in the statistical path model are used in most of the studies included in the meta-dataset. If each variable is only analyzed in a smaller subset of the studysample (as in our case, due to the large set of variables), the approach suffers from the large number of "missing values" and does not converge. Second, in the TTSEM approach only full correlation matrices can be summarized. Hence, the majority of studies would have to be excluded in this approach. Overall, the univariate approach is preferred, since it allows analyzing the introduced complex path model and does not require to cut the number of analyzed variables in the model or the number of studies included in the meta-dataset.

\section{5 | CONCLUSION}

In this meta-analysis, we use reported estimates from a unique sample of 411 empirical studies to test the nexus among capital structure, risk management, and firm value. Here, the aim of this study is to analyze the interaction between capital structure decisions and risk management decisions as well as the channels through which they add value to the firm. The main result from meta- analytic structural equation modelling is that leverage significantly mediates the effect of risk management on firm value. In connection, risk management provides firms with greater debt capacities; however, decision makers should leave debt capacities unused, thus lowering bankruptcy and financial distress costs. Moreover, managers should utilize additionally available internal funds from risk management for carrying out profitable projects as well as promoting research and development activities - the two main drivers of firm value. In this manner, corporate hedging lowers potential underinvestment problems. Hence, our findings concerning the mediating role of capital structure are in line with Gilje and Taillard (2017) stating that corporate hedging especially adds value to the firm by lowering bankruptcy and underinvestment risks. Our moderator analysis further confirms that these relations gain in importance over time. Overall, our findings imply that capital structure decisions and risk management should be jointly considered by managerial decision makers as important drivers for maximization of firm value. Hence, these conclusions constitute scientific confirmation and provide a further justification for the observations from the corporate practices of, among others, Lufthansa Group, OMV, and Royal Philips as presented at the beginning of this article.

Overall, our meta-analytical results are highly relevant to corporate decision-making as well as future developments of management research. Our findings imply that financing decisions (including capital structure and risk management) are important drivers of firm value and should be jointly considered by managerial decisionmakers for firm value maximization along with other important factors, such as product quality (Phillips \& Sertsios, 2013), corporate social responsibility (Servaes \& Tamayo, 2013), and advertising expenditure (Vitorino, 2013). Due to the observed mediating function of capital structure, reported results from direct tests of the risk management-firm value link might induce misleading conclusions and should be carefully interpreted. Instead, future empirical analyses should account for the mediating role of capital structure decisions, implying that consequences of financial decisions have to be considered in an integrated way. Future research questions might cover more fine-grained analyses of the mediating role of corporate financing and other elements of business strategy for risk management, as well as the drivers of heterogeneity for the relations among risk management, capital structure, and firm value. This also includes the analysis of causality between these variables, because the meta-analysis applied in this study does not allow interpretation of causal implications (Bergh et al., 2016). Since we were not able to include further variables, such as proxy variables for the asymmetric information 
friction (Manconi, Massa, \& Zhang, 2018), this might also be the subject of future studies. Further ideas might be the consideration of endogenous relations, such as the relation between dividend policy and capital structure decisions (Crutchley, Jensen, Jahera Jr., \& Raymond, 1999) and the analysis of non-linear effects, which might lead to more accurate results for particular effects (for example, Crutchley et al., 1999).

\section{DATA AVAILABILITY STATEMENT}

The data that support the findings of this study are available from the corresponding author upon reasonable request.

\section{ORCID}

Markus Hang (1) https://orcid.org/0000-0003-0204-400X Jerome Geyer-Klingeberg (iD https://orcid.org/0000-00016615-7439

Andreas W. Rathgeber (10) https://orcid.org/0000-00026996-5631

\section{ENDNOTES}

${ }^{1}$ For example, structural equation modeling is applied in primary analysis by Bartram, Brown, and Fehle (2009), Jin and Jorion (2006), and Graham and Rogers (2002).

${ }^{2}$ For an elaborate and comprehensive summary of the determinants of capital structure, please refer to the studies by Frank and Goyal (2009), Harris and Raviv (1991), Rajan and Zingales (1995), and Titman and Wessels (1988).

${ }^{3}$ Possible indirect effects of hedging activities on firm value via the mentioned determinants are not explicitly tested in the path model.

${ }^{4}$ The studies by Bartram (Bartram, 2019; Bartram et al., 2009; Bartram, Brown, \& Conrad, 2011), Lin et al. (J. B. Lin, Pantzalis, \& Park, 2007; J. B. Lin, Pantzalis, \& Park, 2010), and Nguyen and Faff (Nguyen \& Faff, 2002, 2006, 2007, 2010) are based on the same data sample. As the studies by Nguyen and Faff additionally investigate very similar variables, we had to exclude Nguyen and Faff (2006) and Nguyen and Faff (2010) from our sample as they do not contain additional variables.

${ }^{5}$ Especially financial hedging data is often manually collected from annual reports and, thus, the data collection and preparation might strongly differ also across studies examining similar or overlapping data sets.

${ }^{6}$ For the calculation of $\tau^{2}$ and further explanations of the HOMA procedure, please refer to Borenstein (2009), Carney et al. (2011), or van Essen, Carney, Gedajlovic, and Heugens (2015).

${ }^{7}$ Since mean correlation coefficients are accepted as remarkable in meta-analysis when they exceed 0.10 (Cohen, 1992), we focus especially on the interpretation of determinants, for which the HOMA procedure reveals a mean effect size equal to or larger than 0.10 .

${ }^{8}$ Our results are in line with the findings of studies analyzing the determinants of corporate hedging, which propose that debt ratio has no opposing impact on corporate hedging behavior (Donohoe (2015); Géczy, Minton, and Schrand (1997); GeyerKlingeberg, Hang, Rathgeber, and Stöckl (2018); Nance, Smith, and Smithson (1993); Pérez-González and Yun (2013); Tufano (1996)). For this reason, we do not interpret the reverse causality.

${ }^{9}$ The calculations are based on a weighted least squares estimation with random effects. Since the results do not reveal significant results, they are not reported in the work at hand. The results of the Egger-test are available on request from the authors.

\section{REFERENCES}

Adam, T. R., \& Fernando, C. S. (2006). Hedging, speculation, and shareholder value. Journal of Financial Economics, 81(2), 283-309.

Allayannis, G., \& Weston, J. P. (2001). The use of foreign currency derivatives and firm market value. The Review of Financial Studies, 14(1), 243-276.

An, Z., Li, D., \& Yu, J. (2016). Earnings management, capital structure, and the role of institutional environments. Journal of Banking \& Finance, 68(1), 131-152.

Aretz, K., \& Bartram, S. M. (2010). Corporate hedging and shareholder value. The Journal of Financial Research, 33(4), 317-371.

Arnold, M. M., Rathgeber, A. W., \& Stöckl, S. (2014). Determinants of corporate hedging: A (statistical) meta-analysis. The Quarterly Review of Economics and Finance, 54(4), 443-458.

Baker, M., \& Wurgler, J. (2002). Market timing and capital structure. The Journal of Finance, 57(1), 1-32.

Bancel, F., \& Mittoo, U. R. (2004). Cross-country determinants of capital structure choice: A survey of European firms. Financial Management, 33(4), 103-132.

Bartram, S. M. (2019). Corporate hedging and speculation with derivatives. Journal of Corporate Finance, 57, 9-34.

Bartram, S. M., Brown, G. W., \& Conrad, J. (2011). The effects of derivatives on firm risk and value. Journal of Financial and Quantitative Analysis, 46(4), 967-999.

Bartram, S. M., Brown, G. W., \& Fehle, F. R. (2009). International evidence on financial derivatives usage. Financial Management, 38(1), 185-206.

Bergh, D. D., Aguinis, H., Heavey, C., Ketchen, D. J., Boyd, B. K., Su, P., ... Joo, H. (2016). Using meta-analytic structural equation modeling to advance strategic management research: Guidelines and an empirical illustration via the strategic leadership-performance relationship. Strategic Management Journal, 37(3), 477-497.

Bessembinder, H. (1991). Forward contracts and firm value: Investment incentive and contracting effects. Journal of Financial and Quantitative Analysis, 26(4), 519-532.

Bilgili, T. V., Calderon, C. J., Allen, D. G., \& Kedia, B. L. (2016). Gone with the wind: A meta-analytic review of executive turnover, its antecedents, and postacquisition performance. Journal of Management, 43(6), 1966-1997.

Borenstein, M. (2009). Introduction to meta-analysis. Chichester, England: John Wiley \& Sons.

Bortolotti, B., Cambini, C., Rondi, L., \& Spiegel, Y. (2011). Capital structure and regulation: Do ownership and regulatory independence matter? Journal of Economics \& Management Strategy, 20(2), 517-564. 
Bradley, M., Jarrell, G. A., \& Kim, E. H. (1984). On the existence of an optimal capital structure: Theory and evidence. The Journal of Finance, 39(3), 857-878.

Cambini, C., \& Spiegel, Y. (2016). Investment and capital structure of partially private regulated firms. Journal of Economics \& Management Strategy, 25(2), 487-515.

Card, D., \& Krueger, A. B. (1995). Time-series minimum-wage studies: A meta-analysis. American Economic Review, 85(2), 238-243.

Carney, M., Gedajlovic, E. R., Heugens, P. P. M. A. R., van Essen, M., \& van Oosterhout, H. (2011). Business group affiliation, performance, context, and strategy: A meta-analysis. Academy of Management Journal, 54(3), 437-460.

Carney, M., van Essen, M., Gedajlovic, E. R., \& Heugens, P. P. M. A. R. (2015). What do we know about private family firms? A meta-analytical review. Entrepreneurship Theory and Practice, 39(3), 513-544.

Carter, D. A., Rogers, D. A., \& Simkins, B. J. (2006). Does hedging affect firm value? Evidence from the US airline industry. Financial Management, 35(1), 53-86.

Cheung, M. W. L. (2015). Meta-analysis: A structural equation modeling approach. Chichester, England: John Wiley \& Sons.

Cheung, M. W. L., \& Chan, W. (2005). Meta-analytic structural equation modeling: A two-stage approach. Psychological Methods, 10(1), 40-64.

Chui, A. C. W., Lloyd, A. E., \& Kwok, C. C. Y. (2002). The determination of capital structure: Is national culture a missing piece to the puzzle? Journal of International Business Studies, 33(1), 99-127.

Clark, E., \& Judge, A. (2009). Foreign currency derivatives versus foreign currency debt and the hedging premium. European Financial Management, 15(3), 606-642.

Cohen, J. (1992). A power primer. Psychological Bulletin, 112(1), $155-159$.

Crutchley, C. E., Jensen, M. R. H., Jahera, J. S., Jr., \& Raymond, J. E. (1999). Agency problems and the simultaneity of financial decision making: The role of institutional ownership. International Review of Financial Analysis, 8(2), 177-197.

Donohoe, M. P. (2015). The economic effects of financial derivatives on corporate tax avoidance. Journal of Accounting and Economics, 59(1), 1-24.

Doucouliagos, H., \& Stanley, T. D. (2013). Are all economic facts greatly exaggerated? Theory competition and selectivity. Journal of Economic Surveys, 27(2), 316-339.

Doucouliagos, H., \& Ulubaşoğlu, M. A. (2008). Democracy and economic growth: A meta-analysis. American Journal of Political Science, 52(1), 61-83.

Duran, P., Kammerlander, N., van Essen, M., \& Zellweger, T. (2016). Doing more with less: Innovation input and output in family firms. Academy of Management Journal, 59(4), 12241264.

Egger, M., Smith, G. D., Schneider, M., \& Minder, C. (1997). Bias in meta-analysis detected by a simple, graphical test. British Medical Journal, 315(7109), 629-634.

Fama, E. F., \& French, K. R. (1998). Taxes, financing decisions, and firm value. The Journal of Finance, 53(3), 819-843.

Fauver, L., \& Naranjo, A. (2010). Derivative usage and firm value: The influence of agency costs and monitoring problems. Journal of Corporate Finance, 16(5), 719-735.
Fernandes, N. (2011). Global convergence of financing policies: Evidence for emerging-market firms. Journal of International Business Studies, 42(8), 1043-1059.

Frank, M. Z., \& Goyal, V. K. (2009). Capital structure decisions: Which factors are reliably important? Financial Management, 38(1), 1-37.

Froot, K. A., Scharfstein, D. S., \& Stein, J. C. (1993). Risk management: Coordinating corporate investment and financing policies. The Journal of Finance, 48(5), 1629-1658.

Gamba, A., \& Triantis, A. J. (2013). Corporate risk management: Integrating liquidity, hedging, and operating policies. Management Science, 60(1), 246-264.

Géczy, C., Minton, B. A., \& Schrand, C. (1997). Why firms use currency derivatives. The Journal of Finance, 52(4), 1323-1354.

Geyer-Klingeberg, J., Hang, M., \& Rathgeber, A. W. (2019a). Corporate financial hedging and firm value: $A$ meta-analysis. Augsburg, Germany.

Geyer-Klingeberg, J., Hang, M., \& Rathgeber, A. W. (2019b). What drives financial hedging? A meta-regression analysis of corporate hedging determinants. International Review of Financial Analysis, 61, 203-221. https://doi.org/10.1016/j.irfa.2018.11.006

Geyer-Klingeberg, J., Hang, M., \& Rathgeber, A. W. (2020). Metaanalysis in finance research: Opportunities, challenges, and contemporary applications. International Review of Financial Analysis, 101524. https://doi.org/10.1016/j.irfa.2020.101524 (Forthcoming).

Geyer-Klingeberg, J., Hang, M., Rathgeber, A. W., \& Stöckl, S. (2018). What do we really know about corporate hedging? A multimethod meta-analytical study. Business Research, 11(1), $1-31$.

Geyskens, I., Steenkamp, J.-B. E. M., \& Kumar, N. (2006). Make, buy, or ally: A transaction cost theory meta-analysis. Academy of Management Journal, 49(3), 519-543.

Gilje, E. P., \& Taillard, J. P. (2017). Does hedging affect firm value? Evidence from a natural experiment. The Review of Financial Studies, 30(12), 4083-4132. https://doi.org/10.1093/rfs/hhx069

Graham, J. R., \& Rogers, D. A. (2002). Do firms hedge in response to tax incentives? The Journal of Finance, 57(2), 815-839.

Hall, G., Hutchinson, P., \& Michaelas, N. (2010). Industry effects on the determinants of unquoted SMEs' capital structure. International Journal of the Economics of Business, 7(3), 297-312.

Hamari, J., \& Keronen, L. (2017). Why do people play games? A meta-analysis. International Journal of Information Management, 37(3), 125-141.

Hang, M., Geyer-Klingeberg, J., Rathgeber, A. W., \& Stöckl, S. (2018). Measurement matters-A meta-study of the determinants of corporate capital structure. The Quarterly Review of Economics and Finance, 68, 211-225. https://doi.org/10.1016/j. qref.2017.11.011

Harris, M., \& Raviv, A. (1991). The theory of capital structure. The Journal of Finance, 46(1), 297-355.

Haushalter, G. D. (2000). Financing policy, basis risk, and corporate hedging: Evidence from oil and gas producers. The Journal of Finance, 55(1), 107-152.

Hedges, L. V., \& Olkin, I. (1985). Statistical methods for meta-analysis. San Diego, CA: Academic Press.

Hoskisson, R. E., Chirico, F., Zyung, J., \& Gambeta, E. (2017). Managerial risk taking: A multitheoretical review and future research agenda. Journal of Management, 43(1), 137-169. 
Hovakimian, A. (2006). Are observed capital structures determined by equity market timing? Journal of Financial and Quantitative Analysis, 41(1), 221-243.

Hu, L.-T., \& Bentler, P. M. (1999). Cutoff criteria for fit indexes in covariance structure analysis: Conventional criteria versus new alternatives. Structural Equation Modeling: A Multidisciplinary Journal, 6(1), 1-55.

Hunter, J. E., \& Schmidt, F. L. (2004). Methods of meta-analysis: Correcting error and bias in research findings (2nd ed.). Thousand Oaks, CA: Sage Publications.

Jak, S. (2015). Meta-analytic structural equation modelling. Berlin, Germany [among others]:: Springer International Publishing.

Jensen, M. C. (1986). Agency costs of free cash flow, corporate finance, and takeovers. American Economic Review, 76(2), 323-329.

Jensen, M. C., \& Meckling, W. H. (1976). Theory of the firm: Managerial behavior, agency costs and ownership structure. Journal of Financial Economics, 3(4), 305-360.

Jin, Y., \& Jorion, P. (2006). Firm value and hedging: Evidence from US oil and gas producers. The Journal of Finance, 61(2), 893-919.

Kraus, A., \& Litzenberger, R. H. (1973). A state-preference model of optimal financial leverage. The Journal of Finance, 28(4), 911-922.

Landis, R. S. (2013). Successfully combining meta-analysis and structural equation modeling: Recommendations and strategies. Journal of Business and Psychology, 28(3), 251-261.

Lee, D., Kirkpatrick-Husk, K., \& Madhavan, R. (2014). Diversity in Alliance portfolios and performance outcomes: A meta-analysis. Journal of Management, 43(5), 1472-1497.

Leland, H. E. (1998). Agency costs, risk management, and capital structure. The Journal of Finance, 53(4), 1213-1243.

Lin, C.-M., Phillips, R. D., \& Smith, S. D. (2008). Hedging, financing, and investment decisions: Theory and empirical tests. Journal of Banking \& Finance, 32(8), 1566-1582.

Lin, J. B., Pantzalis, C., \& Park, J. C. (2007). Corporate use of derivatives and excess value of diversification. Journal of Banking \& Finance, 31(3), 889-913.

Lin, J. B., Pantzalis, C., \& Park, J. C. (2010). Corporate hedging policy and equity mispricing. Financial Review, 45(3), 803-824.

Liu, X., van Jaarsveld, D. D., Batt, R., \& Frost, A. C. (2014). The influence of capital structure on strategic human capital: Evidence from US and Canadian firms. Journal of Management, 40 (2), 422-448.

Lookman, A. (2004). Does hedging increase firm value? Evidence from oil and gas producing firms. Pittsburgh, PA.

Loss, F. (2012). Optimal hedging strategies and interactions between firms. Journal of Economics \& Management Strategy, 21(1), 79-129.

Lufthansa Group. (2017). Shareholder information on corporate financial strategy. Retrieved from https://investor-relations. lufthansagroup.com/en/finanzierung-und-cr/finance-strategy. html

Manconi, A., Massa, M., \& Zhang, L. (2018). The informational role of corporate hedging. Management Science, 64(8), 38433867.

Marano, V., Arregle, J.-L., Hitt, M. A., Spadafora, E., \& van Essen, M. (2016). Home country institutions and the internationalization-performance relationship. Journal of Management, 42(5), 1075-1110.
Marcus, B., Taylor, O. A., Hastings, S. E., Sturm, A., \& Weigelt, O. (2016). The structure of counterproductive work behavior. Journal of Management, 42(1), 203-233.

Marsh, H. W., Kit-Tai, H., \& Zhong, W. (2004). In search of golden rules: Comment on hypothesis-testing approaches to setting values for fit indices. Structural Equation Modeling: A Multidisciplinary Journal, 11(3), 320-341.

Miller, M. H., \& Rock, K. (1985). Dividend policy under asymmetric information. The Journal of Finance, 40(4), 1031-1051.

Modigliani, F., \& Miller, M. H. (1958). The cost of capital, corporation finance and the theory of investment. The American Economic Review, 48(3), 261-297.

Myers, S. C. (1977). Determinants of corporate borrowing. Journal of Financial Economics, 5(2), 147-175.

Myers, S. C. (1984). The capital structure puzzle. The Journal of Finance, 39(3), 574-592.

Myers, S. C., \& Majluf, N. S. (1984). Corporate financing and investment decisions when firms have information that investors do not have. Journal of Financial Economics, 13(2), 187-221.

Nance, D. R., Smith, C. W., \& Smithson, C. W. (1993). On the determinants of corporate hedging. The Journal of Finance, 48(1), $267-284$

Nguyen, H., \& Faff, R. (2002). On the determinants of derivative usage by Australian companies. Australian Journal of Management, 27(1), 1-24.

Nguyen, H., \& Faff, R. (2006). Foreign debt and financial hedging: Evidence from Australia. International Review of Economics \& Finance, 15(2), 184-201.

Nguyen, H., \& Faff, R. (2007). Are financial derivatives really valueenhancing? Australian evidence. Melbourne, Australia: Deakin University website Retrieved from https://ideas.repec.org/p/ dkn/acctwp/aef_2007_14.html.

Nguyen, H., \& Faff, R. (2010). Are firms hedging or speculating? The relationship between financial derivatives and firm risk. Applied Financial Economics, 20(10), 827-843.

OMV. (2017). Shareholder information on managing financial risks. Retrieved from https://www.omv.com/portal/01/com/omv/ OMV_Group/investors-relations/Shareholders_Information/ Risk_Management/Financial_Risks

Oort, F. J., \& Jak, S. (2016). Maximum likelihood estimation in meta-analytic structural equation modeling. Research Synthesis Methods, 7(2), 156-167.

Royal Philips. (2017). Shareholder information on corporate risk management. Retrieved from https://www.philips.com/a-w/ about/investor/governance/risk-management.html

Pérez-González, F., \& Yun, H. (2013). Risk management and firm value: Evidence from weather derivatives. The Journal of Finance, 68(5), 2143-2176.

Phillips, G., \& Sertsios, G. (2013). How do firm financial conditions affect product quality and pricing? Management Science, 59(8), 1764-1782.

Rajan, R. G., \& Zingales, L. (1995). What do we know about capital structure? Some evidence from international data. The Journal of Finance, 45(1), 31-48.

Rosenbusch, N., Rauch, A., \& Bausch, A. (2013). The mediating role of entrepreneurial orientation in the task environment-performance relationship. Journal of Management, 39(3), 633-659.

Rosenthal, R. (1979). The file drawer problem and tolerance for null results. Psychological Bulletin, 86(3), 638-641. 
Ross, S. A. (1977). The determination of financial structure: The incentive-Signalling approach. The Bell Journal of Economics, 8 (1), 23-40.

Servaes, H., \& Tamayo, A. (2013). The impact of corporate social responsibility on firm value: The role of customer awareness. Management Science, 59(5), 1045-1061.

Sheng, Z., Kong, W., Cortina, J. M., \& Hou, S. (2016). Analyzing matrices of meta-analytic correlations: Current practices and recommendations. Research Synthesis Methods, 7(2), 187-208.

Smith, C. W., \& Stulz, R. M. (1985). The determinants of firms' hedging policies. Journal of Financial and Quantitative Analysis, 20(4), 391-405.

Stanley, T. D. (2005). Beyond publication Bias. Journal of Economic Surveys, 19(3), 309-345.

Stanley, T. D., \& Doucouliagos, H. (2012). Meta-regression analysis in economics and business. Routledge advances in research methods (Vol. 5). London, England: Routledge.

Stanley, T. D., Doucouliagos, H., Giles, M., Heckemeyer, J. H., Johnston, R. J., Laroche, P., ... Pugh, G. (2013). Meta-analysis of economics research reporting guidelines. Journal of Economic Surveys, 27(2), 390-394.

Strebulaev, I. A. (2007). Do tests of capital structure theory mean what they say? The Journal of Finance, 62(4), 1747-1787.

Stulz, R. M. (1996). Rethinking risk management. Journal of Applied Corporate Finance, 9(3), 8-24.

Titman, S., \& Wessels, R. (1988). The determinants of capital structure choice. The Journal of Finance, 43(1), 1-19.

Tufano, P. (1996). Who manages risk? An empirical examination of risk management practices in the gold mining industry. The Journal of Finance, 51(4), 1097-1137.

van Essen, M., Carney, M., Gedajlovic, E. R., \& Heugens, P. P. M. A. R. (2015). How does family control influence firm strategy and performance? A meta-analysis of US publicly listed firms. Corporate Governance: An International Review, 23(1), 3-24.

van Essen, M., Otten, J., \& Carberry, E. J. (2015). Assessing managerial power theory: A meta-analytic approach to understanding the determinants of CEO compensation. Journal of Management, 41(1), 164-202.

Viswesvaran, C., \& Ones, D. S. (1995). Theory testing: Combining psychometric meta-analysis and structural equation modeling. Personnel Psychology, 48(4), 865-885.

Vitorino, M. A. (2013). Understanding the effect of advertising on stock returns and firm value: Theory and evidence from a structural model. Management Science, 60(1), 227-245.

Zeegers, M., Colonnesi, C., Stams, G.-J., \& Meins, E. (2017). Mind matters: A three-level meta-analysis on parental mentalization and sensitivity as predictors of infant-parent attachment. Psychological Bulletin, 143(12), 1245-1272.

\section{SUPPORTING INFORMATION}

Additional supporting information may be found online in the Supporting Information section at the end of this article.

How to cite this article: Hang M, GeyerKlingeberg J, Rathgeber AW, Stöckl S. Rather complements than substitutes: Firm value effects of capital structure and financial hedging decisions. Int J Fin Econ. 2021;26:4895-4917. https://doi.org/10.1002/ijfe.2045 